\title{
The Iberian ichthyofauna: Ecological contributions
}

\author{
L. Encina ${ }^{1}$, A. Rodríguez ${ }^{2} \&$ C. Granado-Lorencio ${ }^{3}$ \\ Department of Plant Biology and Ecology. Fac. Biology. Un. Sevilla. \\ Av. Reina Mercedes s/n; 41012 Sevilla, Spain \\ 11encina@us.es; ${ }^{2}$ dora@us.es; ${ }^{3}$ granado@us.es
}

\begin{abstract}
The actual Iberian ichthyofauna is the result of the functioning of the aquatic systems and the human activities. For 27 years the Fish Ecology Research Group of Seville University has worked on understanding the complex relationships established around fish in different water systems and from differents approach scales (life strategies, population dynamics, structure and diversity of the communities, energy, etc.). The work carried out through those years has yielded a huge increase in the knowledge of our continental ichthyofauna. Now we are getting closer to understanding the Iberian epicontinental ecosystems and the ecology role of their fish, a basic need for management and conservation purposes.
\end{abstract}

Keywords: Assemblages, biomass, fish, life strategies, production, reservoirs, rivers.

\section{RESUMEN}

La actual ictiofauna ibérica es el resultado tanto del funcionamiento de los ecosistemas acuáticos como de las actividades humanas. Durante 27 años, el Grupo de Investigación de Ecología de Peces de la Universidad de Sevilla ha trabajado en la comprensión de las complejas relaciones que giran en torno a la ecología de los peces de nuestros diferentes ecosistemas epicontinentales, abordándolos desde distintas aproximaciones (estrategias de vida, dinámica de sus poblaciones, estructura y diversidad de sus comunidades, energéticas, etc). Los estudios llevados a cabo a lo largo de estos años han contribuido a incrementar el conocimiento de los ecosistemas acuáticos epicontinentales de la Península Ibérica y el papel ecológico de sus peces, conocimientos ambos básicos para el manejo y la conservación de los mismos.

Palabras clave: Asociaciones, biomasa, embalses, estrategias de vida, peces, producción, ríos.

$Y$ dime tu que es mejor, ¿conciencia de visionario que mira en el hondo acuario esos peces peregrinos que nunca puede alcanzar, o esa terrible tarea de ir echando a la arena, muertos, los peces del mar?

A. MACHADO

\section{INTRODUCTION}

These first lines serve as a tribute -from those who, in the framework of fish, are dedicated to the terrible task of sampling and analysis in order to understand the mechanisms that have originated today's living world, with its richness of forms and adaptative strategies- to Professor Margalef, whose visionary ability has impelled us to want a vital and productive ecology. Popper (1992) said that the natural sciences, together with music, poetry, and painting, make up the greatest fulfilment of the human spirit, as they are all to some extent art, in the sense that engaging in them requires a large dose of imagination. In fact, some ecologists believe that the most-beneficial fruits of this science have occurred when it has involved the trait of genius, a connotation more spiritual than physical, a primitive power of creativity with which certain people are born and which accompanies them as a protective oracle. Genius, as in possession of a vision not obtained through the methodical and professional use of logic, but as 
an innate gift, which has much to do with the direct, calm, and reflexive contact with nature, and which Pianka (1982) denominates biological intuition. Such was the case of Dr. Ramón Margalef. In his own words, a live and fecund ecology is within reach only of those who have their eyes wide open to see, and the intellect with spontaneity sufficient to admire and learn.... that is why ecology requires the contemplation of nature through the eyes of a child.

It was also Margalef (1982) who wrote that the development of theoretical constructs aspiring to generalised expressions with biological sense inevitably entails the contribution of very specific research. Understanding the enormous complexity of nature (the great diversity, not only of species, but also of life strategies, metabolic types, and capacity to use different substrates, or of the different forms of energy found in the biosphere) requires the mobilisation of a large number of specialists and considerable economic support. An ecosystem includes, even in the simplest cases, an extraordinary variety of elements of very different types, each of them subject to continuous variation in their degree of dynamic expression; just the biotic part of any natural ecosystem presents such complexity, that rarely is it possible to make a complete study of it, especially if variations in space and time are included, as these often vary discontinuously, stochastically, and non-linearly. Many years are needed to discover and understand how ecosystems work. As Hilborn and Ludwig pointed out (1993), ecology is not a hard science, it is an arduous one, built up through a slow accumulation of data enabling attempts at synthesis.

For the last 27 years, the Fish Ecology Research Group of Seville University has worked on integrating the science of ecology and the fish group, from both the evolutionary and functional standpoints of aquatic ecosystems. The complex relationships established around fish communities in different water bodies give these organisms a role as integrators in the working of the ecosystem, making them an ideal probe for the ecology of such environments.

From the start, the group endeavoured to acquire a synthesising capacity in its studies, demonstrating the intrinsic unity of the evolutionary and thermodynamic processes (systematic, functional) as the only way to understand the organisation and working of ecosystems, which result from the duality between the structural restrictions operating on the organisms (as a result of the interactions between them and of natural selection), and functional restrictions operating on the processes (concerning the exchange of matter and energy). Few groups have used this holistic concept in tackling the study of fish, examining not only different processes and hierarchical scales (adaptative strategies of the organisms, population dynamics, structure and diversity of the communities, circulation of energy and production, etc.) and environments (rivers, lakes, reservoirs), but also including in their studies variations at both temporal and spatial level.

The first studies were begun at the end of the $70 \mathrm{~s}$ in a setting -the Iberian continental ichthyology - that had been neglected for half a century (Lobón-Cerviá, 2001). The work of Luis Lozano Rey (1935) on the fluvial fish of Spain marked the end of a whole generation of ichthyologists who disappeared with the Civil War. After the hostilities, the study of the epicontinental fish came to an almost complete stop, resulting in the enormous lack of basic knowledge characterising the first years of the Group's research. The causes of such neglect were various, the most notable being the absence of commercial and sporting species (except for the trout and the salmon), and possibly also the low diversity of our continental ichthyofauna, compared with other European ones (Doadrio et al., 1991, 2001; García-Novo, 2000). It was precisely this situation of ignorance and neglect that acted as incentive for the new generation of ichthyologists emerging at the end of the $70 \mathrm{~s}$, in a society sensitive to biological and environmental matters; ichthyologists who took up the torch to study fish from different biological approaches, among them those who would regard the fish as analytical tools in the consolidation of ecological theory. The work carried out through those years has yielded a huge increase in the knowledge of our 
continental ichthyofauna, providing a knowledge base enabling us to advance in our perception of the faunistic and ecological reality of the Iberian Peninsula. To understand this has been a scientific challenge and a basic need in the management and conservation of our deteriorated continental aquatic ecosystems. The society that sustains us is calling for solutions, and will continue to do so during this 21 st century. Understanding nature is the only way to manage it ecologically (Granado, 1996).

In 1978, study was begun of the ichthyofauna in the Arrocampo reservoir. It was the first one on reservoir ichthyofauna carried out in the country, and the first in which this zoological group dealt with the context of ecological theory. The study was both an enormous conceptual and methodological challenge and a doorway to broadening the perspectives of study, searching for the root of the processes observed. Understanding the properties of these ecological systems, the processes from colonisation to adaptation of the species in the new ecosystem, how they develop, function, and respond to perturbation (management), inevitably meant understanding the evolutionary dynamics of the populations in their environment of origin: the river. This was the approach used to study the fluvial courses during the following years. In the same way, and following the same interests, not only was the typology of the studied water masses (lenitic and lotic) extended, but also the levels of organisation (organisms, populations, communities, ecosystems) and of processes were analysed: aspects of the biology of the organisms related with life strategies, such as growth, feeding and reproduction; analysis of the fish assemblages, their composition and regulation over time; the distribution of trophic resources; the occupation of the aquatic habitat, and the relationships with other components of the system (prey and predators), without omitting topics of conservation and management (Fig. 1).

The application of innovatory elements of sampling has yielded further knowledge about many of the species of our ichthyofauna and the characteristics of our assemblages, in both rivers and reservoirs (Fig. 2). In particular, the use of methods pertaining to the biology of fishing (fishing gear) and hydroacoustic techniques has

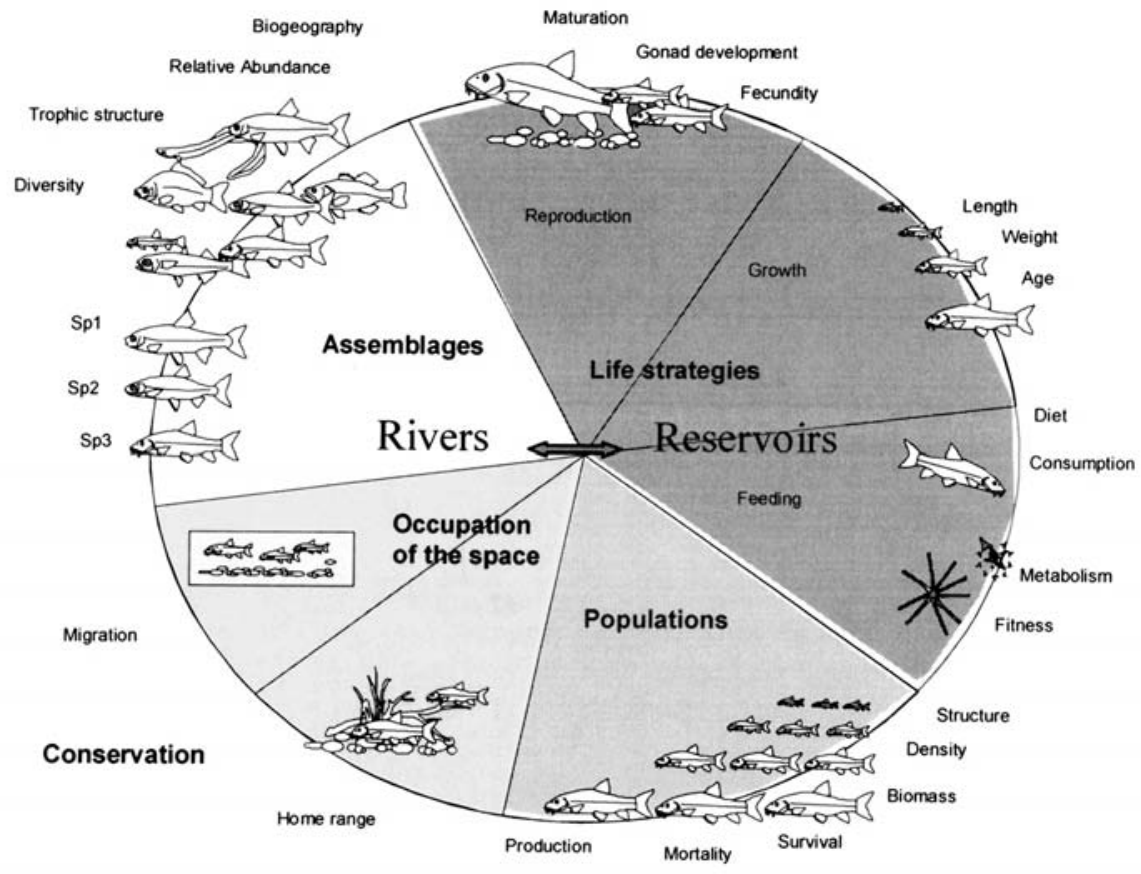

Figure 1. Research carried out by the Fish Ecology Group of Seville University on the ecology of the freshwater fish. Aspectos tratados en el estudio de la ecología de los peces epicontinentales por el Grupo de Investigación. 
enabled the evaluation and quantification of fish biocoenoses in large water bodies (large rivers, reservoirs, and lakes). It was even possible to check the integrity of the methodology, in a huge scientific experiment at natural scale (rarely performed), when the Joaquín Costa reservoir was emptied (Granado et al., 1996, 1997, 1998). Currently we are using prospective and evaluative techniques that enable us to propose integral management of aquatic ecosystems.

One of the certainties arrived at over the years of experiment is the need for integrated studies, prolonged in time and broad in space, as the only way to obtain results fitting the reality of nature. For instance, we possess one of the longest European series for studies of diversity and biomass of reservoir fish, which has yielded a knowledge of how the fish populations of an ecosystem have evolved over time, and the relationship with and adaptation to the use and management of the aquatic resource (Almaraz Nuclear Power Station, 1978-2005). We are getting closer and closer to understanding how the Iberian epicontinental ecosystems and their ichthyofauna work; but much research remains to be done, and many hypotheses must be checked. New lines of work open as each project closes. Such is the case of the role of the scale, not only in the processes, but even in the sometimes powed methodological protocols we use in our studies (and on which is based the whole analytical construction of the science). Scales (above all, spatial ones) are rarely incorporated in the sampling protocols and the experimental designs. For this reason, they are today an important challenge that must be confronted.

\section{THE IBERIAN ICHTHYOFAUNA}

If we ponder on some aspects of the Iberian ichthyofauna, we will encounter a series of paradoxical situations that warrant a brief comment. First, the fact that, although the group of Iberian vertebrates with the greatest evolutionary success, fish have played (at least until very recently) a modest role in the scientific and conservationist interests of this country. A reflection of this is their almost symbolic presence in programmes of conservation by the organisms responsible for protection of the fauna. However, a high percentage of our species are unique for the biodiversity of the planet. The geological history of the Peninsula has shaped a

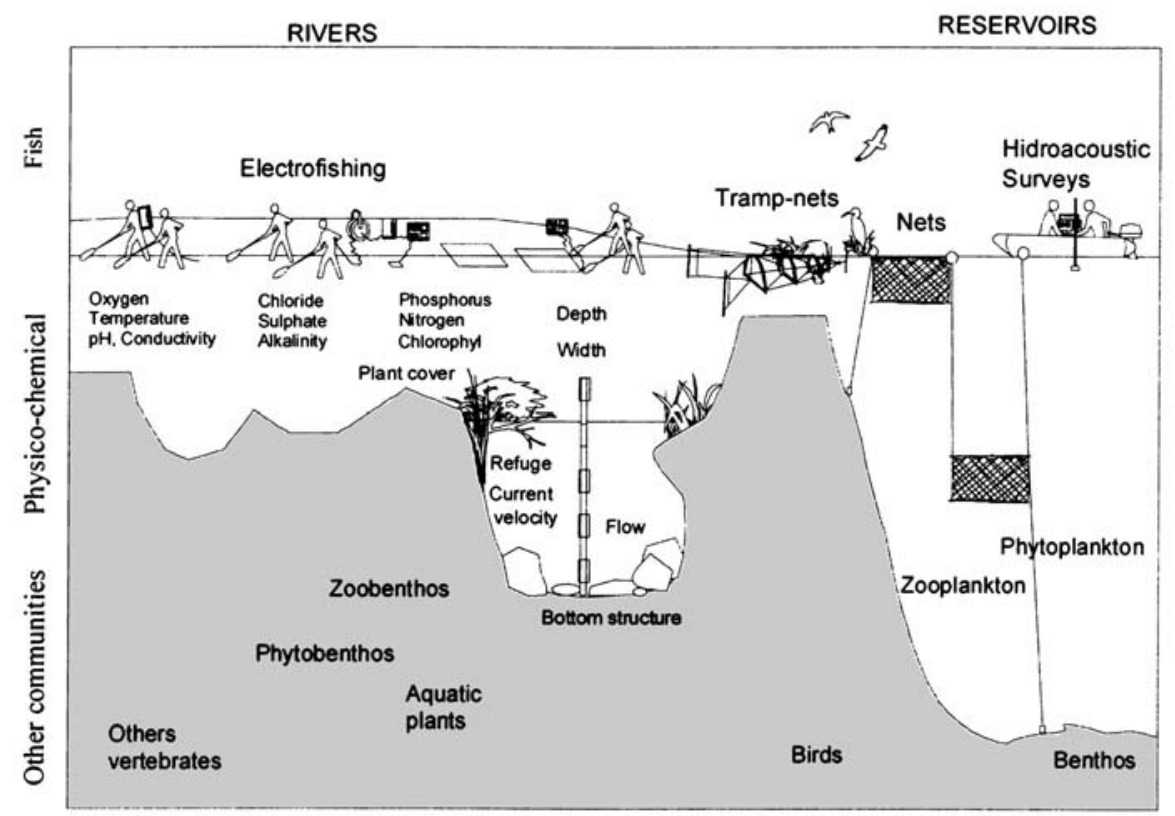

Figure 2. Sampling methodology applied to rivers and reservoirs. Estrategia general de muestreo aplicada en ríos y embalses. 
unique and generally little-known continental ichthyofauna. Situated in the extreme south of Europe, it served long ago as a bridge for species flow between the old continent and Africa, until being converted into a biogeographical island with the appearance of the Pyrenees mountain system and the Strait of Gibraltar. This isolation gave rise to the post-Oligocene differentiation of the present-day Iberian endemisms. Of all the families with Iberian distribution, those of greatest evolutionary radiation are Cyprinidae and Cobitidae. The former is the more diverse, with 23 species, and the one contributing more endemisms (Doadrio et al., 1991; Granado, 1996; Doadrio, 2001).

Secondly, despite the fact that the biogeographical peculiarities of the Peninsula have given rise to a fairly exclusive ichthyofauna, the overall species richness is very restricted, as shown by the number of (native) species in relation to the size of the Iberian hydrographic basins. The reason can be found in the nature of the environ-
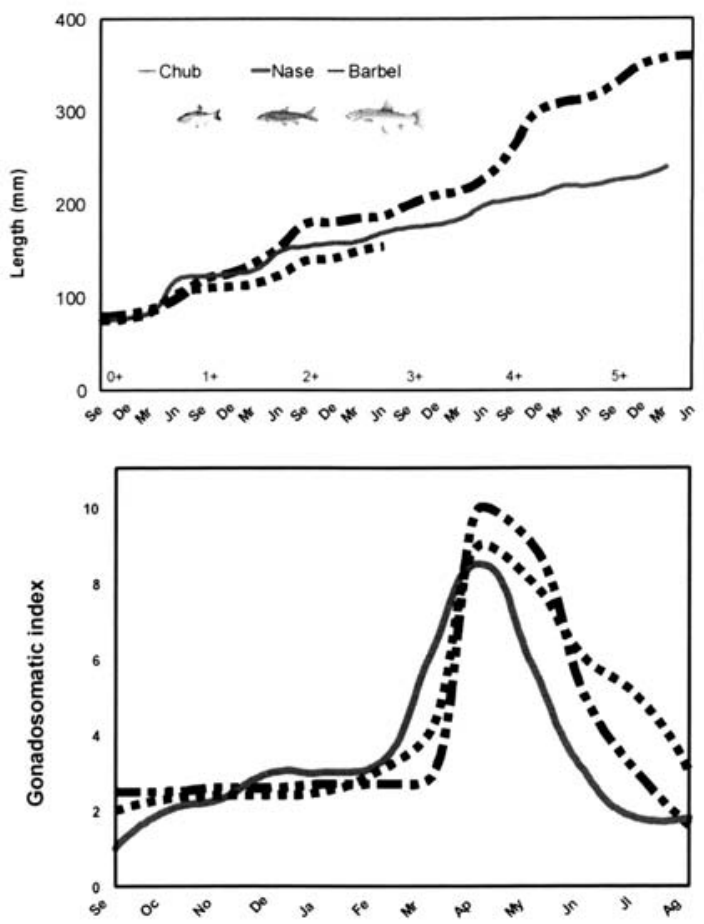

Figure 3. Patterns of growth of chub, nase and barbel (up) and their gonad development (below) in the Guadalete River. Patrón de crecimiento del cachuelo, la boga y el barbo (superior) y desarrollo gonadal (inferior) en el Río Guadalete. mental matrix of our aquatic ecosystems, characterised by strong, frequent, and unpredictable fluctuations, both intra- and inter-annual; there is a pattern of diversity which shows a trend towards an increase along the east-west axis and from north to south (Granado, Op. Cit.).

Lastly, although no less surprising, is the paradox regarding the aquatic ecosystems in which our fish live. Spain, until yesterday (in evolutionary terms) a country of rivers, has become one of large volumes of dammed waters. That is, it has passed from a predominance of lotic environments to one of lenitic environments, with all that entails for certain organisms (the actors, to paraphrase Hutchinson, 1981), which have evolved through geological eras adapting life strategies, metabolic types, capacities of resource use, etc. on stages -the rivers- diametrically opposed to those of the ecological theatre in which human activity has led them to act.

\section{LIFE STRATEGIES}

The study of life strategies covers a broad spectrum of characteristics of the organisms, such as age, growth, ageing, reproduction, feeding, ethology, etc., which attempt to respond to the fitting of these to the environment in which they live. Practically all the species of Iberian epicontinental fish have evolved within the functional framework of the rivers. The most important characteristic of the majority of our fluvial systems is their intermittence, with periods of torrentiality and of drought. Our fluvial ecosystems are undoubtedly the paradigm of unpredictability in the natural systems of the Peninsula. In these environments, the fish have developed optimal adaptative strategies for their survival over time (population structure, time of reproductive maturity, mortality rates, feeding, spatial movements, etc). This ecosystem-species coevolution has given rise to very characteristic life cycles in our fish fauna, so that their behaviour patterns in the hydrological regime of our rivers are similar. Such behaviour is one of typically altricial life styles: that is, short life, rapid 
growth, early sexual maturity and early reproduction, high fecundity, and high reproductive investment, and the possibility of multiple reproductions, together with a certain degree of opportunism and generalism in their diets.

The studies carried out over numerous years in the Upper Guadalete River show that these life styles are the best option possible when facing such fluctuating environments. In this ecosystem, three cyprinid species coexist: Iberian barbel (Barbus sclateri), Iberian chub (Leuciscus pyrenaicus), and Iberian nase (Chondrostoma willkomii). The river, situated in the south of the Iberian Peninsula, rises in the Sierra de Grazalema, the wettest point in Spain. The torrentiality and steep slope of the headwaters produce catastrophic spates during winter. However, the rapid drainage of the basin, together with the summer's scarce rains and high temperatures, makes the river lose its continuity during low water, forming pools where the fish are subjected to a strong environmental stress. These two situations cause great seasonal losses and population exhaustion, although the losses are moderated by the life strategies of the three species.

The highest growth rates are in the first years of life. The annual pattern fits a sinusoidal-type curve, with a rapid increase from the end of spring until well into autumn, coming practically to a stop during the winter and beginning of spring (Fig. 3). Sexual maturity is early; this (in detriment to the somatic growth) serves to maximise the number of reproducers and the number of descendants produced, a potential with which to recolonise after perturbations (RodríguezRuiz, 1992; Rodríguez-Ruiz et al., 1998). The reproductive cycle is adapted to the production cycle of the system, so that the first stages of gametogenesis, which require a lesser energy investment, take place during the winter; while the final stages, with a strong energy cost, take place in the period when the diversity, abundance of food, and productivity of the system are at a peak (spring), the temperatures are favourable, and the metabolic requirements still moderate (Encina, 1991; Encina and Granado, 1997a,b,c) (Fig. 3). The progeny hatch in the summer, when there is a high production of small prey, which proliferate as a consequence of the slower flow, and which constitute one of the main components in the diet of the fry of the three species. At the same time, the risk of spates -and thus the loss of the spawn- is minimal in this period. Lastly, the high temperatures favour a rapid growth of the young of the year (YOY).

The fluctuating nature of the environment not only sets the patterns of growth and reproduction -it also sets the convergence in the type of trophic strategy of these three species. Except in the nase, with a marked detritivorous stenophagy, the feeding strategy is characterised by generalism and omnivory (Fig. 4). The high trophic plasticity of Iberian barbel and chub enables them to change the type of prey and the energy ingestion, adapting to the availability of resources in the environment (both seasonally and ontogenetically); in the most-unfavourable periods, there is always detritus as an available resource (and which the nase exploits throughout its life). Detritus is widely recognised as a food source in fluctuating ecosystems, where at times it may even be the only resource available (Hofer 1991; Magalhaes 1992; Encina et al., 2004).

The common strategy developed by the species of the upper Guadalete River (rapid growth, early sexual maturity, high rates of reproduction, trophic generalism, and rapid dispersion) follows an evolutionary model that can be generalised to all the fish populations living in our unpredictable fluvial environments. The aim is to exploit the temporary waves of production in the system and optimise the reproductive process (that is, perpetuate the species, and persist) (Granado, 1992; Granado et al., 2000).

When a reservoir is constructed, the lotic ecosystem is replaced by a lenitic one, with completely different characteristics. The variation in the functional regime of the aquatic system alters the physico-chemical and biological conditions of the water. The processes of thermal gradient and anoxia at the bottom of many reservoirs make the resources unexploitable for the fish and other organisms. The loss of the bankside habitats in turn causes the deterioration (or complete disappearance) of the typical biocoenoses of these zones, an important trophic and 
spatial resource (above all for refuge and reproduction) for the ichthyofauna. The river populations, with adaptative strategies evolved in accord with their working, invade the available space and attempt to adapt their life styles to the new system. On the efficiency of such adaptation will depend the growth of the individuals, the density of the population, the capacity to exploit the new resources on offer, and in short, their persistence in the ecosystem.

Like many of our rivers, the reservoirs are highly fluctuating and unpredictable ecosystems, so that in them also, the life strategies best suited to this type of environment are altricial ones. The species in most Iberian rivers have life styles that a priori correspond to the best option possible in the face of stressed or fluctuating environments, and are thus potentially apt for colonising the new environment. However, not all are able to persevere in it. In some cases, this is due to physico-chemical factors (increased temperature, lack of oxygen, increased turbidity, etc.), in others, hydrological ones (the loss of flow may be sufficient to exclude some species), and in most, biological ones (mainly concerning the loss of the former

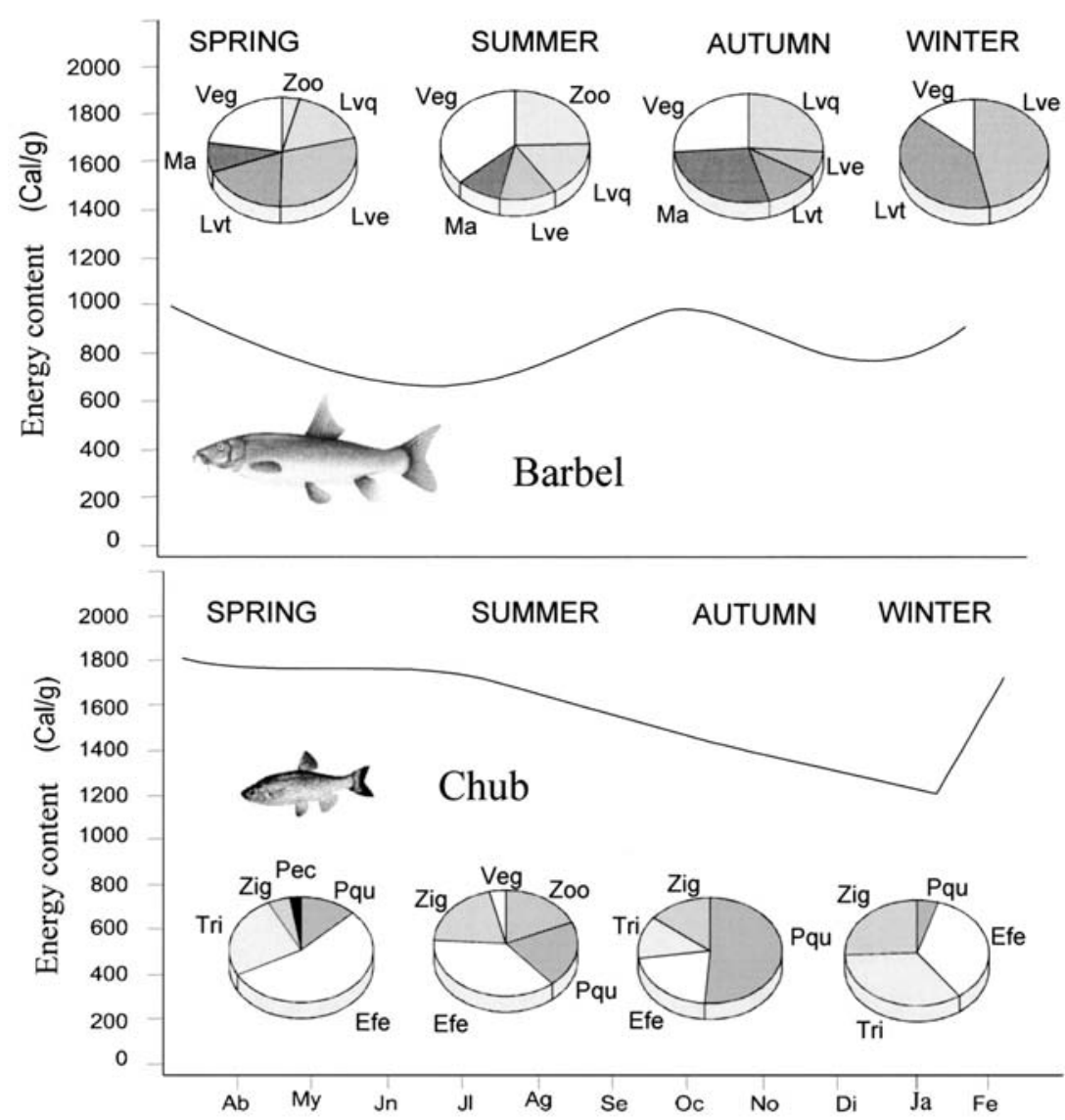

Figure 4. Seasonal changes of the diet and energy content of barbel and chub in the Guadalete River.

Efe: Ephemeroptera (adults); Lve: Ephemeroptera larvae; Lvq: Chironomids larvae; Lvt: Trichoptera larvae; Ma: Macrophits; Pec: Fish; Pqu: Chironomids pupae; Tri: Trichoptera (larvae and adults); Veg: Vegetable remains; Zig: Zigoptera larvae; Zoo: zooplanktonic crustaceans. Composición estacional de la dieta y contenido energético del barbo y el cachuelo en el Río Guadalete.

Efe: Efemerópteros (adultos); Lve: Larvas de efemerópteros; Lvq: Larvas de quironómidos; Lvt: Larvas de tricópteros; Ma: Macrófitas; Pec: Peces; Pqu: Pupas de quironómidos; Tri: Tricópteros (larvas y adultos); Veg: Restos vegetales; Zig: Larvas de zigópteros; Zoo: Crustaceos zooplanctónicos. 
trophic resources and/or reproductive incapacity in the new medium). Only those species able to exploit the new trophic resources offered by the reservoir will become established (totally or temporarily) in the ecosystem; of these, only those able to incorporate new recruits, either by being able to close their life cycle (reproduce) in the reservoir, or by maintaining a flow of populating individuals between the reservoir and the river during reproduction and recruitment, will persist in the fish assemblage. To this must be added the biotic factors arising in the new system, such as competition and depredation.

The small cyprinid species so typical of our fluvial ecosystems (chub, loach, pardilla, etc.) cannot live in the reservoirs, not only because of the multiple problems inherent to the reservoir, but also because of their demanding requirements regarding reproduction, substrates, physico-chemical conditions, etc. Nor can those species making trophic or reproductive migrations from the sea (such as sand smelt and eel), which become trapped in the reservoir and die out with the passage of time. With regard to those that manage to colonise the water mass, it has to be said that there is no evidence to date that any reproduce in the reservoir. That is, all need to reproduce in the river, so that to close their life cycle they must at least migrate during the period of spawning (such is the case of barbel, nase, and trout). Only the exotic species (such as carp, black bass, sunfish, mosquitofish, etc.) are able to reproduce in the reservoirs, although another question concerns the success of their egg-laying, very sensitive to the frequent changes in level caused by management of the water (Fig. 5).

Of the autochthonous species that have been able to colonise these new water masses, the most successful are possibly barbel and nase. The two taxa, faced with the creation of these new ecosystems, have altered certain aspects of their life cycle related with growth, reproduction, and incipient mechanisms of resource exploitation, with ethological adaptations regarding spatial distribution (in both the damtailwater and bathymetric axes), etc. The numerous studies carried out in different reservoirs of the Peninsula do indicate the existence of cer- tain changes in the biology of these taxa when they colonise a reservoir. For instance, regarding growth, the individuals in the reservoirs attain a greater size (for the same age) than those living in the respective river, and also live longer. At the same time, the condition and nutrition (expressing welfare) of the individuals is better in the reservoirs, and fluctuate less. Possibly the cause is that the reservoirs, despite being fluctuating systems, are more stable than the rivers feeding them, with strong and unpredictable perturbations. With regard to reproduction, there is a marked earlier gonadal maturity (favoured by the higher temperature) in the individuals of the reservoir, enabling them to be ready to spawn when the reproductive migration towards the rivers starts (Granado et al., 2000).

Another important change reported concerns trophic habits. In contrast to the river, the reservoirs present a trophic chain that is mainly planktonic. The reservoir leaves few trophic possibilities for the native species colonising it, apart from that of exploiting the new and abundant resources generated: phyto- and zooplankton. Although the barbels are able to exploit the zooplankton (essentially in spring and summer, when this is a very plentiful resource, and the anoxia of the hypolimnion reduces the resources of the benthos), its production (and more so that of the phytoplankton) is not exploited efficiently, and sediments to the bottom. Most of the energy available in the system is thus channelled via the detritivorous route (Encina and Granado, 1990, 1997; Encina et al., 2001). Nase and barbel exploit this resource efficiently, but while the trophic plasticity of the barbel, faced with changes in the availability of system resources, gives it a broader diet and a greater efficiency in exploiting resources, the detritivorous stenophagy of the nase seems to be a disadvantage in the persistence of this species in the reservoirs (even though in the first stages of colonisation it usually has a more expansive growth in population). This is seen particularly when the resource is limited to bankside zones, as happens during low water, because in these habitats the barbels and the introduced species are potentially more competitive. 


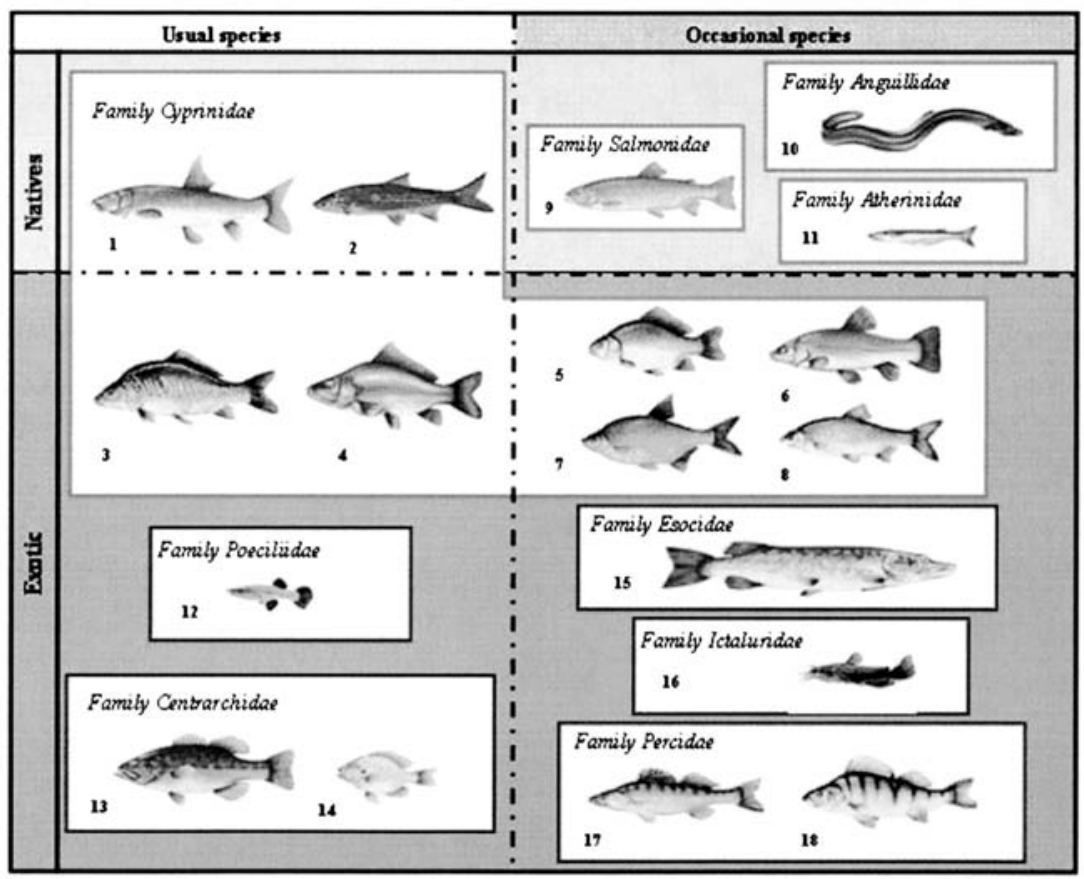

Figure 5. Fish species captured in reservoirs.

1: Barbel (Barbus sp.); 2: Nase and madrilla (Chondrostoma sp.); 3: Mirror carp (Cyprinus carpio var specularis); 4: Common carp (Cyprinus carpio); 5: Goldfish (Carassius carassius); 6: Tinca (Tinca tinca); 7: White Bream (Blicca bjoerkna); 8: Roach (Rutilus rutilus); 9: Common trout (Salmo trutta); 10: Eel (Anguilla anguilla); 11: Kingfish (Atherina presbyter); 12: Mosquitofish (Gambussia affinis); 13: Black bass (Micropterus salmoides); 14: Sunfish (Lepomis gibbosus); 15: Pike (Esox lucius); 16: Catfish (Ameiurus melas); 17: Pikeperch (Stizostedion lucioperca); 18: Perch (Perch fluviatilis). Especies icticas capturadas en embalses. 1: Barbos (Barbus sp.); 2: Bogas y madrillas (Chondrostoma sp.); 3: Carpa de espejo (Cyprinus carpio var specularis); 4: Carpa común (Cyprinus carpio); 5: carpín (Carassius carassius); 6: Tenca (Tinca tinca); 7: Brema blanca (Blicca bjoerkna); 8: Rutilo (Rutilus rutilus); 9: Trucha común (Salmo trutta); 10: Anguila (Anguilla anguilla); 11: Pejerrey (Atherina presbyter); 12: Gambusia (Gambussia affinis); 13: Black bass (Micropterus salmoides); 14: Pez sol (Lepomis gibbosus); 15: Lucio (Esox lucius); 16: Pez gato (Ameiurus melas); 17: Lucioperca (Stizostedion lucioperca); 18: Perca (Perca fluviatilis).

\section{FISH ASSEMBLAGES}

The fluctuating nature of the Iberian rivers also shapes the main characteristics of the Iberian fish assemblages: low diversity, lax organisation, dominated by abiotic and stochastic factors, with short trophic chains of low efficiency. We have already remarked that the biodiversity of the continental fish of the Iberian Peninsula, as a group, is low, both for biogeographical reasons and because of the perturbing nature of our aquatic environments. This low biodiversity also originates assemblages with marked dominances, and in which the mortality caused by environmental fluctuations is preponderant in population regulation and in structuration of the assemblages.
Thus, the local species richness comes from the convergence between the potential richness of the biogeographical area and the unpredictability of the fluctuation to which it is subjected. From these develop ecological processes that determine the final richness of species in the area. It can therefore be assumed that from a richness determined by biogeographical factors, ecological mechanisms are produced that finally fashion the assemblages. It is noteworthy, however, that although these unstable environments generally present assemblages with a much simpler structure than those developed in stable environments, the former are much more resistant (the capacity to return to the initial state after a perturbation). The assemblages are constantly organising and 

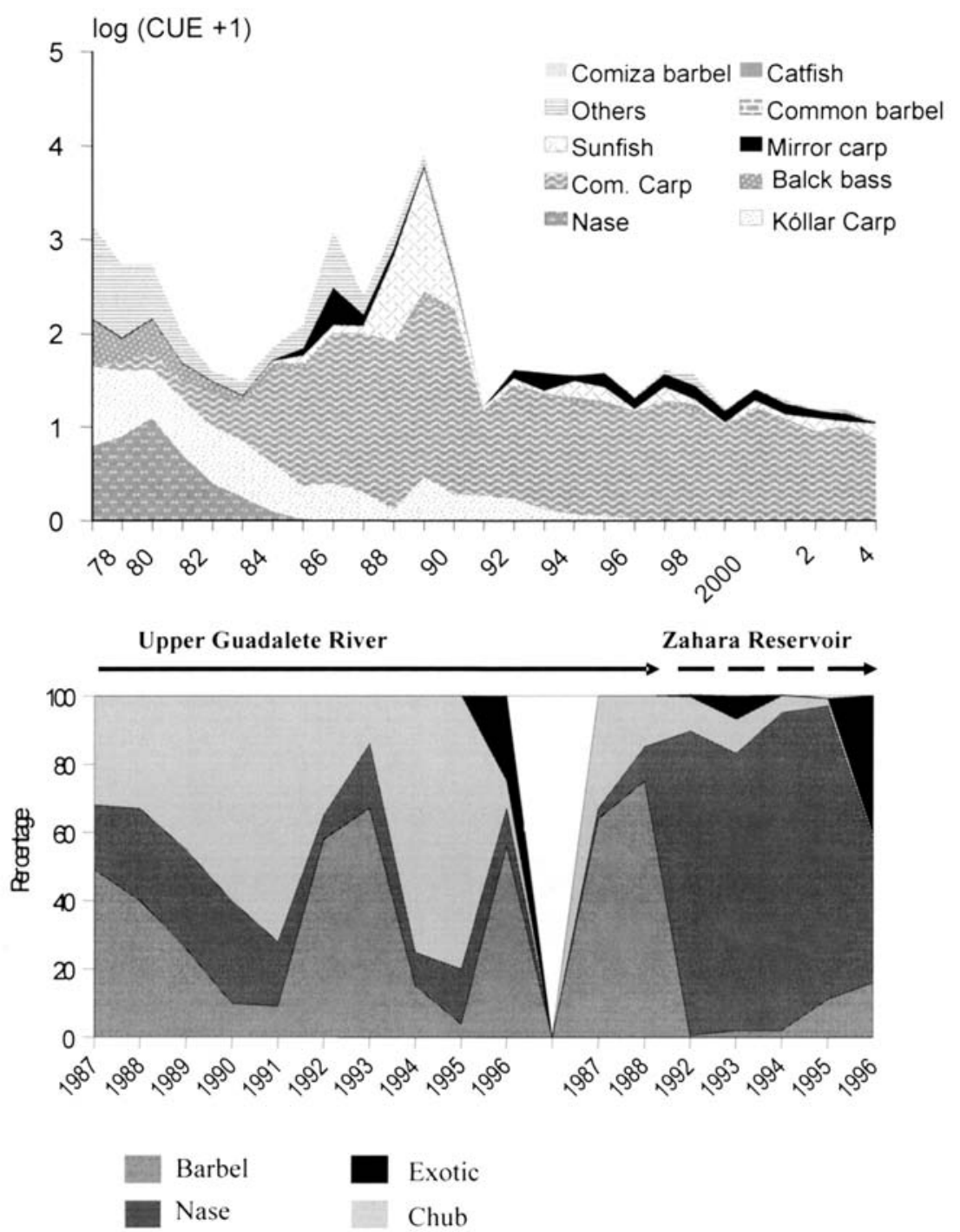

Figure 6. Changes in the fish composition species of the fish assemblage of the Arrocampo stream (up) and of the upper Guadalete River (below) after the filled of the Arrocampo and Zahara reservoirs respectively. Cambios en la composición íctica de la asociación de peces del arroyo Arrocampo (superior) y de la cabecera del río Guadalete (inferior) tras el llenado de los embalses de Arrocampo y Zahara.

disorganising, depending on the seasonal hydrological regime (flood vs. drought). During floods, the high rate of current disorganises the assemblages, which are restructured during periods when the system is stable.

The autochthonous fish associations of the nival and transitional rivers, characterised by high summer flow and lack of supply in the cold season, comprise salmonids (common trout and occasionally sea trout and salmon). In the other, intermittent, fluvial environments the associations are dominated by cyprinids. The species diversity increases along the river from the upper towards the stuary. This is a consequence of an increase in the heterogeneity of the habitat, a greater capacity to buffer the perturbing phenomena down-river, and the incorporation of estuarine species in the last stretch (both slackwater-tolerant species and amphidromic or diadromic ones) (Granado, 2000). 
The patterns of species richness and diversity in the reservoirs are generally governed both by ecological factors and by purely historical factors and the management of the water. Assuming the insular character of a reservoir, the species composition of the assemblage can be considered as the result of the interaction, over time, of the mechanisms of immigration and extinction. On one hand, the size (available volume) determines the number of species and of their individuals able to colonise it (space limitation), and on the other, the number of potentially colonising species will be related with the pool present up-river in the hydrographic basin (which could be considered regional richness). Initially, the number of species in the reservoir will depend partly on accessibility to the colonisers - a merely mechanical property or function (routes of accessibility) - and partly on their capacity to live in this ecosystem (adaptability, ecological plasticity of the taxa). To this will have to be added the indiscriminate introduction of exotic species which all the reservoirs in this country systematically suffer (neodiversity). With time, the fish assemblage of the reservoir undergoes a series of changes related on one hand with the processes of colonisation and the capacity of dispersion of the species (both native and exotic), and on the other with the mechanisms of interaction and adaptation between the phenotype of these species and the behaviour of the water bodies. The fish assemblage shaped by all these processes is, in most cases, very different from the original one of its river location.

These processes have been well documented in the Arrocampo and Zahara reservoirs, in which the evolution of the fish assemblage has been monitored from their filling (Fig. 6). At first, there are very intense changes in the original ichthyofauna of the river, notably the disappearance of most of the native ichthyofauna. Only a few species colonise the space rapidly, becoming dominant. Later, other species appear, and the dominance is divided (Granado, 1996; Rodríguez-Ruiz et al., 2002). For example, in the two reservoirs studied, the nase, characterised by a detritivorous feeding, increased rapidly in population and was the first to colonise the water body, becoming the dominant species. After the initial phase, its populations decreased: in the case of Zahara, it was replaced by a dominance of barbels, while in Arrocampo, from which it was impossible to make the reproductive migration to the river, the species disappeared from the reservoir. At the same time, various exotic species began to appear, introduced for sporting or other interests - carp, black bass, sunfish, etc. - increasing the species richness of the reservoir and completing the trophic network of the assemblage.

As in the rivers, these assemblages are characterised by their low structuration. Most of them are non-interactive, without species saturation or processes of competition caused by density (except perhaps in some isolated or special cases). The factors responsible for the assemblage are the fluctuations, independent of density, and the limited ability of the colonisers to invade and occupy the habitat. Generally, there is a dominance of just a few species (never more than three), called essential species, widely distributed and abundant, accompanied by the so-called satellite species, of reduced distribution, associated to particular habitats and of limited expansion.

The Joaquín Costa reservoir (Barasona), whose fish richness is unusually high among Spanish reservoirs, is a paradigm of mixed assemblage, comprising native (three) and exotic (six) species (Fig. 7). The reasons for this high diversity include the type of use of the reservoir (irrigation) and the considerable flow of the river feeding it, which each year contributes individuals of all the species sheltering in the stretches up-river from the reservoir, together with the introduction of exotic species. The assemblage is not persistent over time: there are habitual resident species, with individuals in the reservoir throughout the year, and others with only seasonal presence (Granado et al., 1998; Encina et al., 2004). Four trophic habits are clearly distinguished: detritivores (madrilla (Chondrostoma miegii)), zooplanktophages (roach), omnivores, (barbel, carp, and white bream), and depredators (trout 

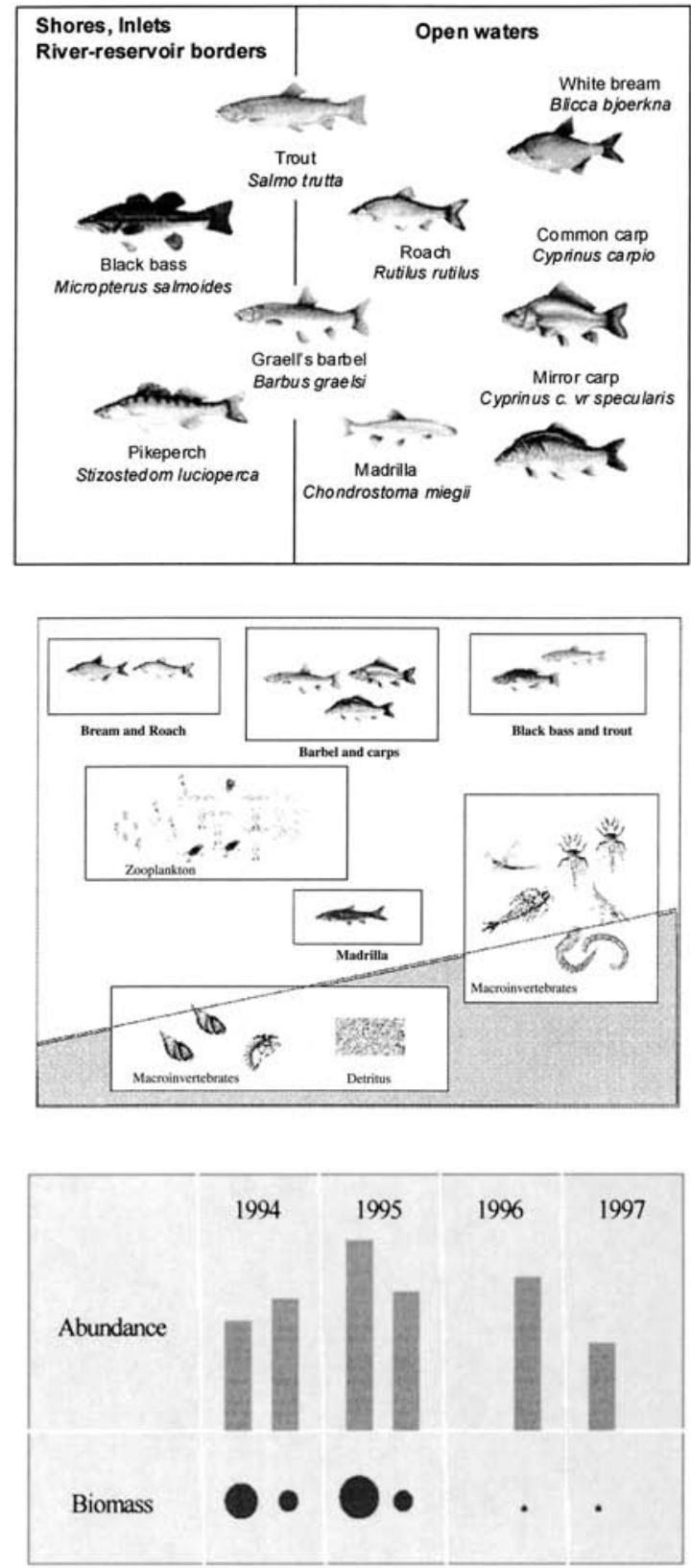

Figure 7. Fish assemblage of Joaquín Costa's Reservoir (Up), trophic guilds (middle) and effects of the casting of the reservoir on the abundance and biomass of fish (below). Asociación ictica del embalse de Joaquín Costa (superior), gremios tróficos (central) y efectos del vaciado del embalse sobre la abundancia y biomasa de peces (inferior).

and black bass). The monitoring of the emptying of this reservoir during two consecutive cycles showed the high elasticity of the species that usually comprise reservoir assemblages, enabling them to return to the pre-perturbation situation in a relatively short time. Following the emptying, the species richness fell (mainly due to the loss of the introduced exotic taxa), but colonisation from the rivers (Ésera and Isábena) by juveniles of the native species meant that there were no differences in abundance before and after emptying; in contrast, the biomass was much lower, as the assemblage comprised much smaller individuals.

\section{OCCUPATION OF THE SPACE}

Within the aquatic ecosystem, the fish are not distributed randomly; they select only certain parts of the whole available habitat, following determinate patterns that are laid down by various factors. In the rivers, each stretch, and each habitat within it (rapids, pools, tables), has its particular physico-chemical characteristics, enabling the establishment of certain species. The reservoir also presents a heterogeneity of environments (dam, tailwater, creeks) and a functional pattern that determines the occupation of the species in time. In both cases it may be that the fish select those microhabitats in which they can most efficiently exploit the resources as a result of their morphoanatomical characteristics (adaptative affinity), occupying those zones in which interactions with other species are minimised (avoiding competition or depredation), or occupying the space without apparent motive (randomness). The occupation of the space could not have to be temporally identical; the organisms can move about, attempting to optimise their existence and to reconnoitre the habitat in order to exploit the available resources necessary for their growth, metabolism, and reproduction. From this standpoint, the fish moves more or less depending on the availability and spatial concentration of the resources (taking these to mean not only food, but also places of shelter or reproduction, or whatever other environmental factor necessary for the organism).

An example of synergic action between chance and necessity in the occupation of the 


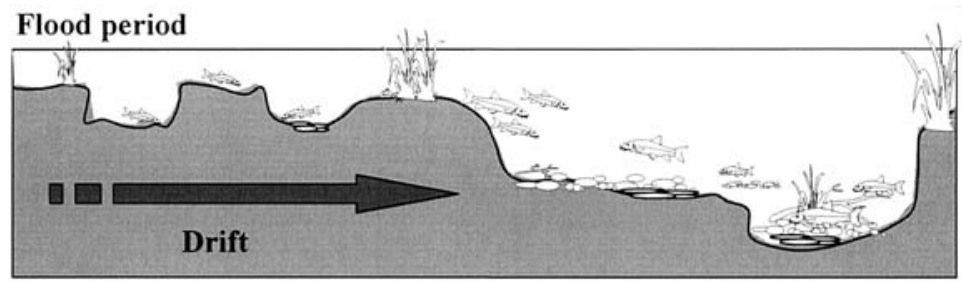

Intermediate period
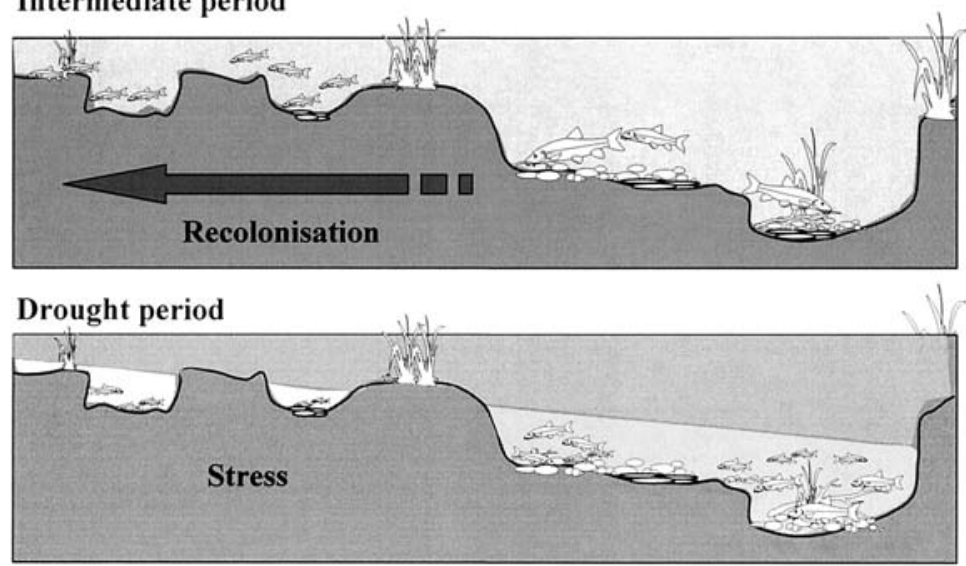

Figure 8. Seasonal changes in the fish's occupation of the space in the upper Guadalete river throughout the annual cycle. Ocupación de los diferentes hábitats en la cabecera del río Guadalete durante los periodos de crecida y estiaje.

space can be found in the results of the studies of microhabitat carried out in the River Guadalete (Fig. 8). During the periods of floods, the drag from the rising water causes the organisms to drift, until they find shelter in zones down-river such as pools, etc. The species, depending on their capacities and on chance, are distributed at random. Later, when the flow has decreased, the populations go upriver, recolonising the devastated stretches. Whereas the process of drifting is random and unspecific, and affects all the species and cohorts, that of recolonisation is determined by the species and its swimming ability. During low water, when the water level is minimum, the organisms are concentrated in the pools, with conditions of overcrowding, nocturnal anoxia, and in some cases, generalised mortality. The individuals that survive this period of environmental stress colonise the river in the following period, causing a demographic explosion of the species that are attempting to occupy the newly recreated space.

Also in the reservoirs, the space-time distribution of the populations corresponds largely to
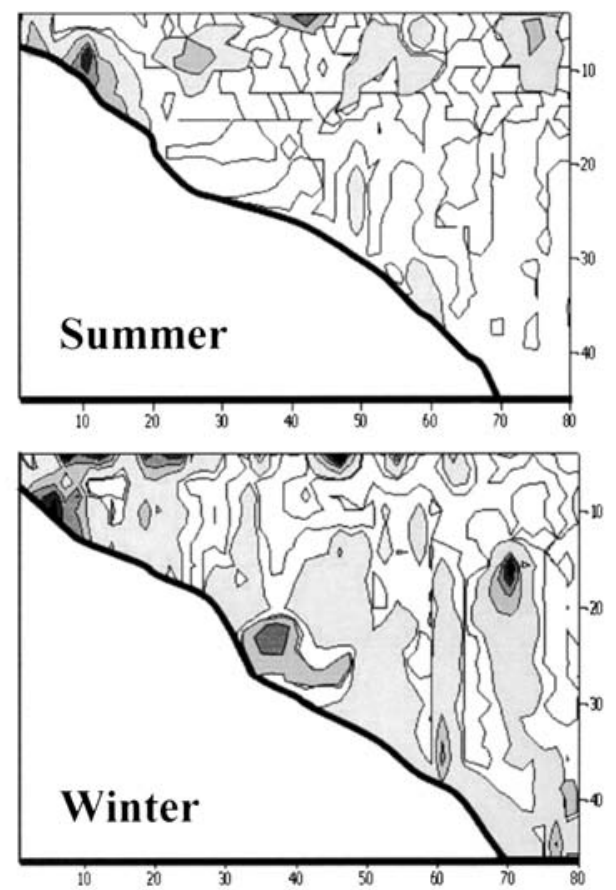

Figure 9. Fish distribution in the Torrejón reservoir during the periods of water stratification (up) and it mixes (below). Distribución batimétrica de las poblaciones de peces en el embalse de Torrejón durante los periodos de estratificación (superior) y mezcla (inferior). 


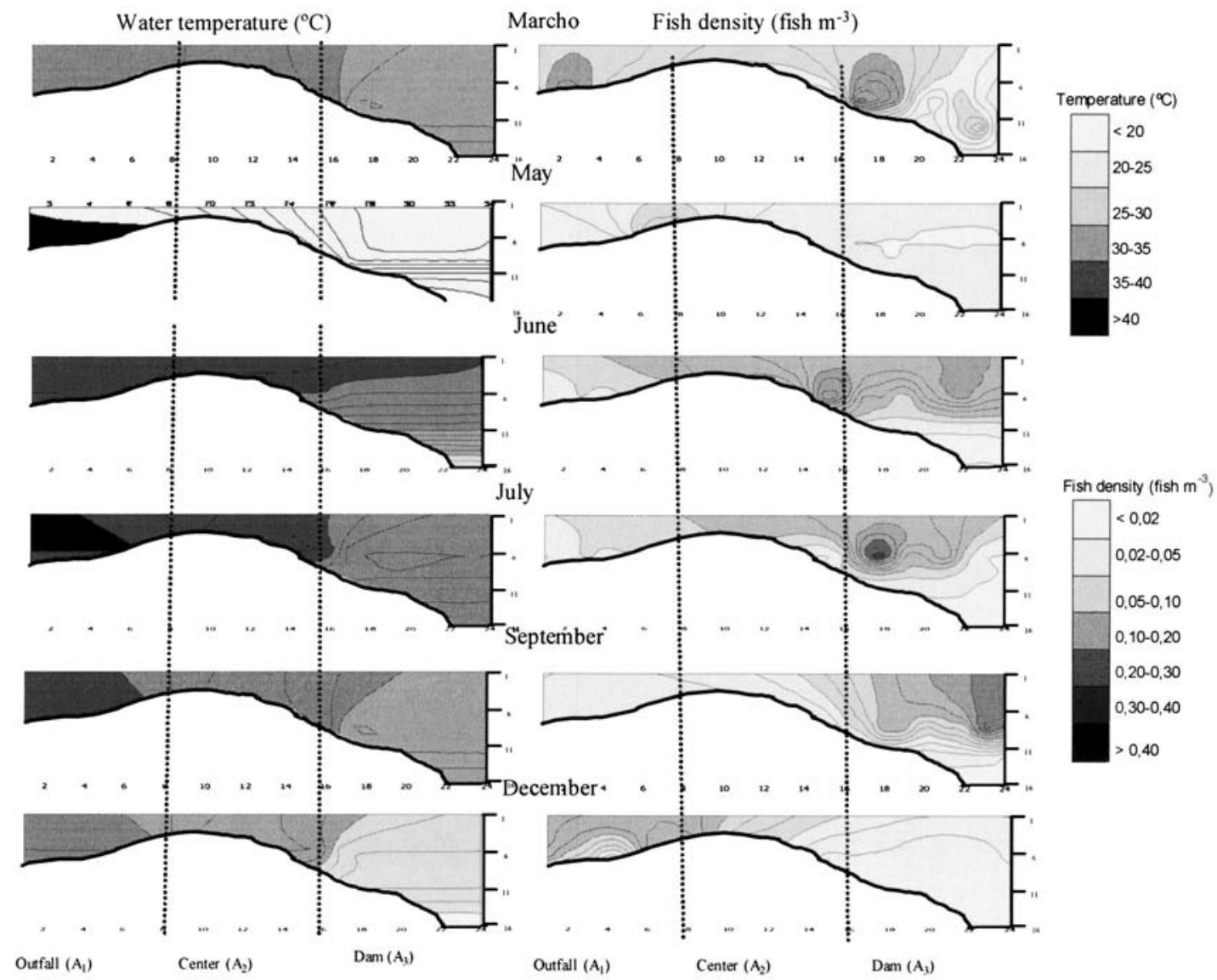

Figure 10. Distribution of temperatures and of fish density in Arrocampo reservoir during the annual cycle. Distribución de las temperaturas y de las densidades de peces en el embalse de Arrocampo durante el ciclo anual.

factors that are exogenic, environmental, determined by the physico-chemical variables and the limnological cycle of the water mass. Related with these, displacements of the fish populations are recorded in the bathymetric axis, the bankside zone/pelagic zone axis, and the dam-tailwater axis of the reservoir. The trend in most reservoirs is that the spatial distribution of the fish during most of the year is associated to the shallowest habitats (bankside zone, central area, and above all, tailwater), with the zones near the dam presenting the lowest occupation. At the same time, the period of stratification affects the general pattern of population distribution; during the mixing periods, fish distribution is throughout the water column, with a trend towards colonising the deep zones; during the stratification of the reservoir, the fish density is greater in the epilimnion, particularly if there are problems of oxygen concentration in the hypolimnion (Fig. 9). One of the most-notable spatial displacements recorded in reservoirs is possibly that made by the fish populations of Arrocampo reservoir as a mechanism of ethologic adaptation to the thermal cycle of the water mass, associated to the working of the Almaraz nuclear power station (Fig. 10). This consists of a seasonal toggling between the warmest zone of the reservoir (the outlet of hot effluent from the reactor) and the coolest zone (that of the dam), which enables the subsistence of these populations in a really extreme environment.

A special case of spatial displacement is the reproductive migrations (potamodromy) that take place in the rivers of temperate regions. Such migrations are well-documented for the genera Barbus and Chondrostoma in the rivers of the Peninsula. These cyprinids go up-river in 
spring in an ecological and evolutionary effort to maximise the efficiency in the exploitation of trophic resources. The species maintain this type of cycle after they have occupied the water mass of the reservoir. During a certain period of the year (usually from February to May or June, depending on the species and the reservoir), the populations go up the tributaries in search of zones of clear, well-oxygenated water with beds of sand, gravel, or macrophytic vegetation on which to lay their eggs (Rodríguez-Ruiz and Granado, 1992; Encina and Rodríguez-Ruiz, 2002; Vela, 2003). The studies made in the Bornos and Zahara reservoirs indicate that the environmental variable of greatest importance in detonating migration in both cases was temperature, which was also the one exercising greatest control on the rate of migration. It is noteworthy that these reproduction-related migratory movements of the species do not overlap in either space or time (Figs. 11 and 12). This space-time separation between species possibly confers adaptative advantages regarding the exploitation of resources; at the same time, such stepped process reduces as much as possible the likelihood of genetic exchange between species, given that fecundation is external, and occupation of the same sites for spawning could give rise to a high rate of hybridisation, undesirable for the species and the viability of the offspring.

\section{FISH ABUNDANCE, BIOMASS AND PRODUCTION}

The environmental conditions, the abundance of ecological resources in the environment, and the net contribution of energy from feeding, determine the abundance of the populations, their biomass, and their production. Fish production is the result of the biomass, recruitment, and instantaneous rates of growth and mortality of the populations, and is especially sensitive to the state of the population and to the effects

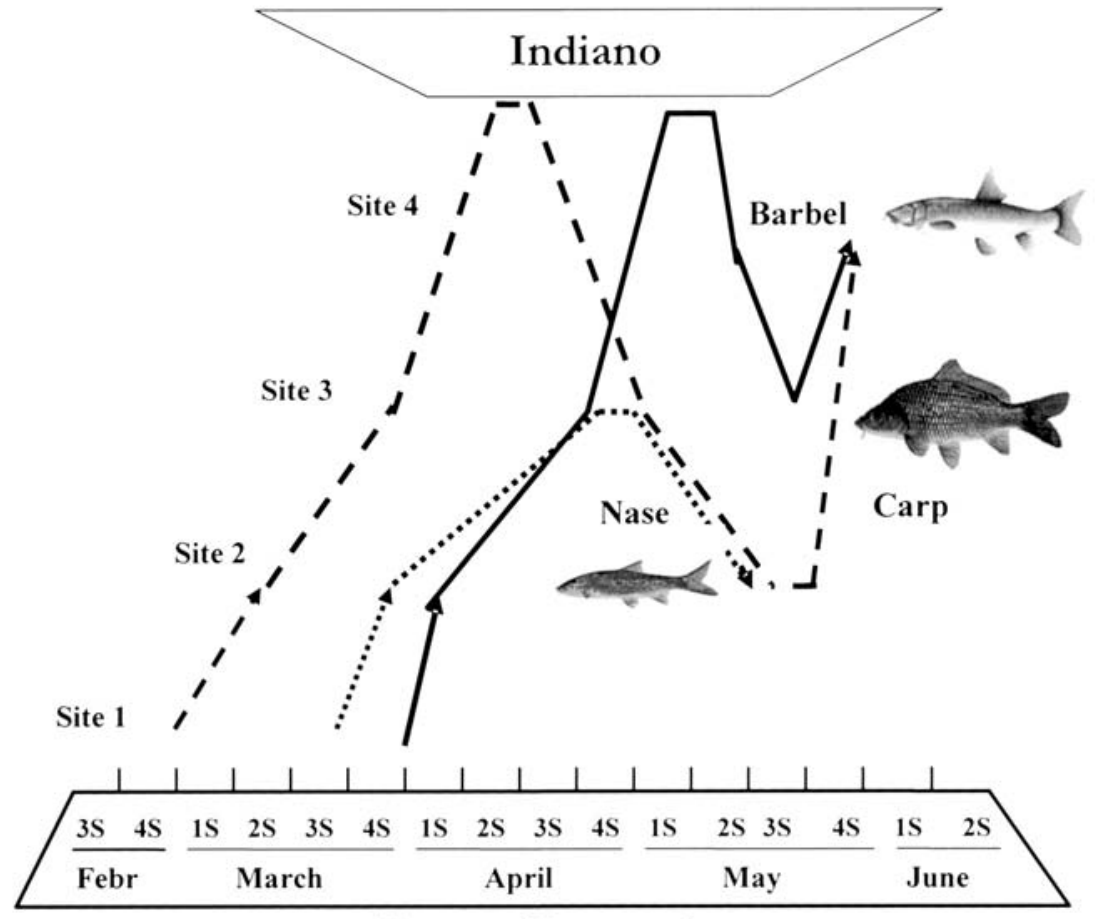

Bornos Reservoir

Figure 11. Reproductive migration of carp, nase and barbel from the Bornos reservoir until the Indiano dam (middle of Guadalete river). Migración reproductiva de carpa, boga y barbo desde el embalse de Bornos hasta el aduz del Indiano (tramo medio del río Guadalete). 

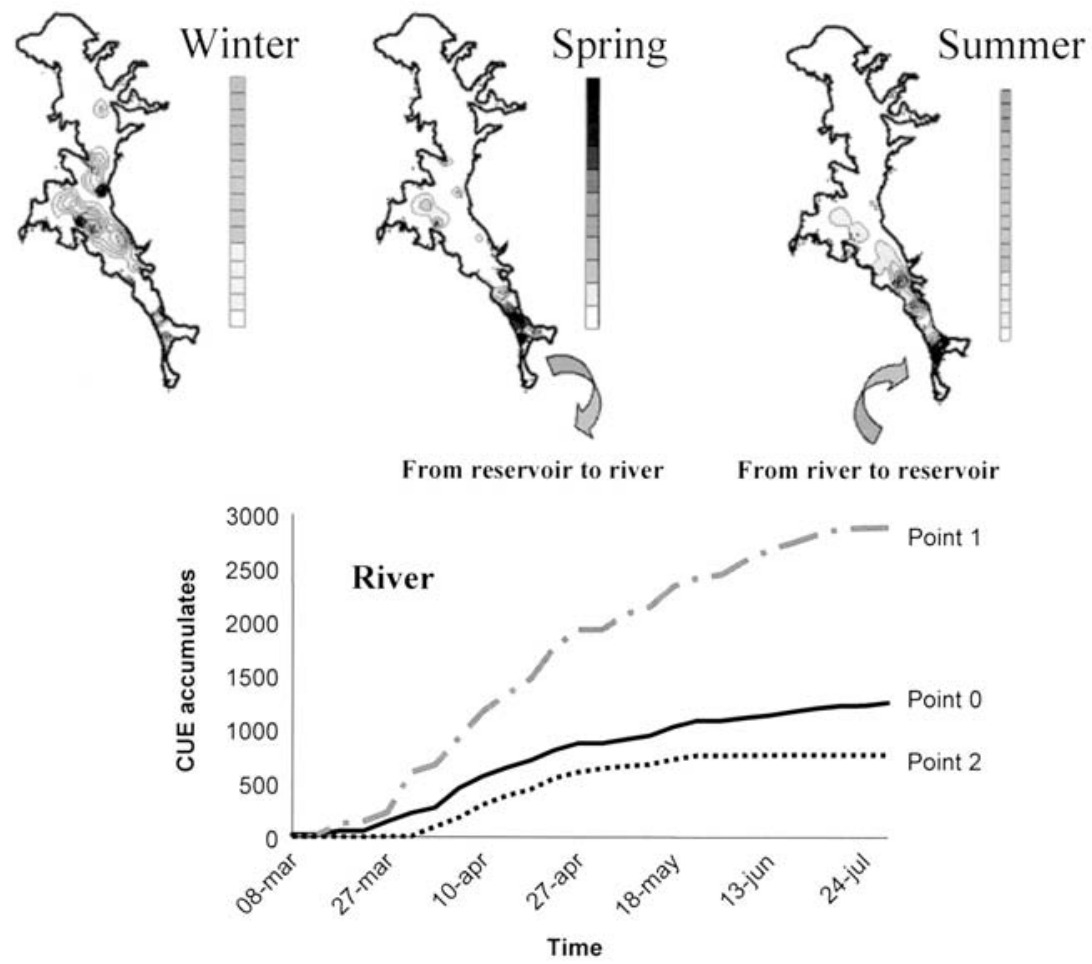

Figure 12. Reproductive migration of the nase from the Zahara reservoir toward the upper Guadalete River (being the point 0 the nearest to the tail of the reservoir and the point 2 the one located more in upper of the river). Migración reproductiva de la boga desde el embalse de Zahara hacia la cabecera del río Guadalete (siendo el punto 0 el más cercano a la cola del embalse y el punto 2 el situado más en cabecera del río).

brought about by environmental changes. The differences observed between the various ecosystem studied (rivers vs. reservoirs), and, within them, between the different water bodies, are the result of the coming together of many factors (both abiotic and biotic).

The fish production recorded for the rivers of the Peninsula is extremely variable, making comparison very difficult. In some cases, estimates have been made by sampling just one stretch of the river. However, it is known that the density and production of fish populations tend to describe a non-symmetric bell curve, so that the intermediate stretches have higher productions than the final ones and the headwaters. This means that the values obtained in a single stretch are not extrapolable to the river set. At the same time, given that individuals usually move about in the river (displacements that can be very intense and far, as occurs in the reproductive migrations), any estimate made at a particular moment in the seasonal cycle of the ecosystem may not be very representative of the production - not only of the river, but even of the stretch. In turn, catastrophic phenomena such as floods or drought have a profound effect on fish production. In general, the rivers dominated by salmonids present lower fish productions than those dominated by cyprinids. The reasons for this difference are found essentially in the temperature (the salmon rivers or stretches are colder) and in the position in the trophic chain (production decreases in species occupying a high trophic level). In any case, fish production in the rivers is lower (given their nature and that of their populations) than in the lakes and reservoirs (Fig. 13).

In the reservoirs, abundance and biomass are associated to the evolution of the water mass from the time of filling. The pioneer-coloniser stage is characterised by a process of expan- 
sion, with high abundance and biomass; this phase is followed first, after a time that varies depending on the climatic, geographical, and trophic conditions, by a second phase damping the initial expansion, with a decrease of the ichthyomass, population and individual growth rate, and simplification of the fish community. This depressive period, tending towards population balance, will fluctuate over time depending on the management of the water. The phase of maturity could be considered a stage of stabilisation and adaptation between the species and the ecosystem (energy flow and nutrient cycle). This stage is, however, rarely reached in Spanish reservoirs, precisely because of the management to which they are subjected: the less fluctuant the reservoir, the more stable will be the fish production over time (as is the case of the Arrocampo reservoir); in contrast, if the water mass is subjected to intense changes (because of its physiography, the hydrology of the basin, or its management), or the reservoir is very open (in reference to the number of tributaries; as for example the Torrejón reservoir), the fish production will undergo intense interannual variations.

\section{PROBLEMS OF THE CONTINENTAL ICHTHYOFAUNA AND CONSERVATION}

Most of our epicontinental fish species, many of them seriously threatened, have, faced with an urgent need of conservation, the handicap of anonymity. Either because they lack sporting or commercial interest, or simply because they are not visible or attractive, our fish are ignored or unknown by society. According to García-Novo (1997), it is not that the attitude is negative, of rejection, but simply of passiveness, as if the fish did not exist; only when a high mortality brings them out from their virtual existence, is the population conscious of their presence. This situation is truly contradictory if we consider that the continental fish are much more abundant in number, and wider in distribution, than many of the vertebrates that are so jealously protected and enjoy programs of conservation and recovery in Spain. Currently, the ichthyofauna of the Iberian Peninsula is the most-threatened of Europe (Elvira, 1990, 1997; Doadrio, 1997). Some species (unique in the biodiversity of the planet) have disappeared in the last century, others are seeing their populations or area of distribution drastically reduced, and others are almost extinct (ghost species); they will probably also pass uneventfully into history and their niche (though not their tomb) will surely be occupied by some introduced species without any sort of remedial action on the part of anyone (not even the administration); after all, for Spanish society the ichthyofauna of our rivers and reservoirs consists of the introduced species (enormous carp, aggressive black bass or pike, record catfish, etc.). The historical (palaeoecological) studies carried out in different rivers demonstrate the general degradative process taking place in our fluvial basins, especially of migratory species such as sturgeon and eel, and estuarine ones such as Allis or Thwaite shads, and the proliferation of allochthonous species in the river community.

Through the years of study in epicontinental aquatic ecosystems we have encountered numerous problems concerning the Iberian fish species: pollution of the water, fragmentation of the rivers by mill- or irrigation dams, destruction of the habitat and its replacement by another type of ecosystem, such as the construction of reservoirs or the introduction of exotic species (some depredators, other strong competitors).

The pollutant tippings sporadically caused by industry are usually conspicuous, and their consequences, evidenced by the associated mortality of fish, manifest. However, the anoxic tippings that often affects to the reservoirs also cause plumes of mortality that can extend many kilometres, depending on the water flow, and they are equally damaging, although less known or considered. Together with pollution, the most important destabilising factor for our autochthonous fauna is the increase in large-scale hydraulic works (mainly reservoirs), whose effects on the autochthonous fauna have been extensively commented on in the previous sections. 


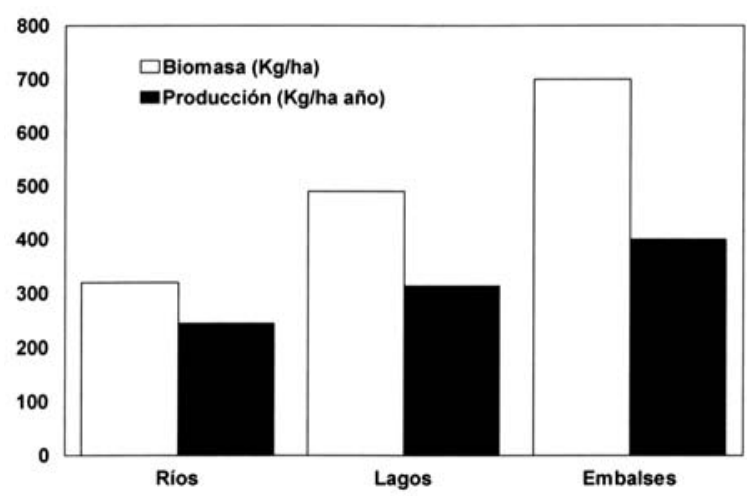

Figure 13. Mean fish biomass and production in rivers, lakes and reservoirs of the Iberian Peninsula. Biomasa y producción ictica media en ríos, lagos y embalses de la Península Ibérica.

The introduction of exotic species is one more of the most-important threats to our fauna. In some cases, the effects have already been demonstrated (Vargas, 1993; Rincón et al., 1990; Elvira, 1996; Elvira et al., 1997), while in others they either have not been proven or (more probably) have still not been sufficiently investigated. There are many reasons for the appearance of exotic species in our waters, from official introductions carried out by public organisms (from the Middle Ages until the last century) to well-intentioned sentimentalist releases (such as the pets that grow too much in our aquaria), or furtive introductions by anglers, accidental escapes, etc. These exotic species are already part of our habitual ichthyofauna, and in many (more and more) aquatic environments even exceed the number of native species of the assemblage. In some cases, they are species of erratic and isolated presence that present no danger, either because of their small population's size or because they are not able to establish themselves in our environments (loricarids, cyclids, and other groups that have been reported from time to time in some ecosystems). Of much more concern is the increasing number of exotic species able to spend their whole life cycle in our aquatic ecosystems. These are species coming essentially from Central Europe and America (pike, zander, white bream, black bass, catfish, sunfish, killifish, and mosquitofish, among others). The adaptability of many of these species to our aquatic environments and those per-

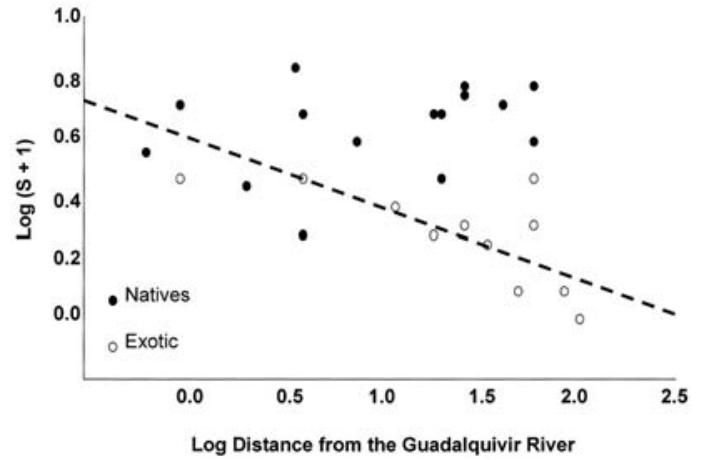

Figure 14. Relationship among the biodiversity of species of different fish assemblages reported in seven rivers of the Guadalquivir basin and the distance to the Guadalquivir river. Relación entre la riqueza de especies de diferentes asociaciones ícticas inventariadas en 7 ríos de la cuenca del río Guadalquivir y la distancia al mismo.

taining to empty trophic niches in our autochthonous assemblages (ichthyophages, planktophages) makes them ecologically very aggressive taxa. Reservoirs and great fluvial courses act as foci of dispersion for the introduced species. A study made in 7 rivers of the Guadalquivir basin found, for example, that the number of exotic species increased as the tributary approached the main axis (Guadalquivir) (Fig. 14).

Many human activities threaten our fish fauna. The problem, however, concerns not only the fish; it is the ecosystem as a whole that is threatened and which must be the object of conservation and protection. It is of no use investing in programs to recover a species if there is not another in place to recover the habitat. This means conserving the aquatic environment, the connestability of the corridors of interchange between areas, together with the restoration of degraded zones and drained populations, and the defence of continental water courses, levels and quality. The exclusiveness of our ichthyofauna should be more than enough reason for its conservation to interest not only scientists, but also politicians, administrators, and society in general.

\section{ACKNOWLEDGEMETS}

We would like to thank to every people who had worked with us through those years, every peo- 
ple who had reported us valuable comments, ideas and recommendations; to ours teachers, mainly Dr. Margalef, who's visionary and genius ability has impelled our work in order to understand the living world. The researchs carried out were only possible due to a lot of financial support. We thank to several DGICYT Projects subventions, to General Direction of Hydraulic Works, CEDEX, CENTA, Andalusian's Scientific Programs subventions, and Almaraz-Trillo Nuclear Power Plant.

\section{REFERENCES}

DOADRIO, I. 1997. Conservación de las especies autóctonas españolas. En: Conservación, Recuperación y Gestión de la Ictiofauna Continental Ibérica. C. Granado-Lorencio (ed.).: 67-74. Publicaciones de la Estación de Ecología Acuática. Sevilla.

DOADRIO, I. 2001. Origen y evolución de la ictiofauna continental española. En: Atlas y Libro Rojo de los Peces Continentales de España. I. Doadrio (ed.).: 20-34. CSIC y Ministerio de Medio Ambiente. Madrid.

DOADRIO, I.; B. ELVIRA. Y Y. BERNAT. 1991. Peces continentales españoles. Inventario y clasificación de zonas fluviales. M.A.P.A.; ICONACSIC. Madrid. 221 pp.

ELVIRA, B. 1990. Iberian endemic freshwater fishes and their conservation status in Spain. J. Fish. Biol., 37: 231-232.

ELVIRA, B. 1996. Native and exotic freshwater fishes in Spanish river basins. Freshwat. Biol., 33: 103-108.

ELVIRA, B. 1997. Impacto y control de los peces exóticos introducidos en España. En: Conservación, Recuperación y Gestión de la Ictiofauna Continental Ibérica. C. Granado-Lorencio (ed.).: 139-151. Publicaciones de la Estación de Ecología Acuática. Sevilla.

ELVIRA, B., G. NICOLAS \& A. ALMODÓVAR. 1997. Pike and red swamp crayfish: a new case of predator-prey relationship between aliens in Central Spain. J. Fish. Biol., 48: 437-446.

ENCINA L. Y C. GRANADO-LORENCIO. 1990. Morfoecología trófica en el género Barbus (Pisces, Cyprinidae). Limnetica, 6: 35-46.

ENCINA, L. 1991. Ecología trófica y dinámica energética de la comunidad íctica del río
Guadalete. Tesis Doctoral. Universidad de Sevilla. Sevilla. 327 pp.

ENCINA, L. \& C. GRANADO-LORENCIO. 1997a. Seasonal changes in condition, nutrition, gonad maturation and energy content in barbel, Barbus sclateri inhabit a fluctuating river. Environmental Biology of Fishes, 50: 75-84.

ENCINA, L. \& C. GRANADO-LORENCIO. 1997b. Seasonal variations in the physiological status and energy content of somatic and reproductive tissues of chub, Leuciscus pyrenaicus. Journal of Fish Biology, 50: 511-522

ENCINA, L. \& C. GRANADO-LORENCIO. 1997c. Seasonal variations in condition and energy content of somatic and reproductive tissues of nase, chondrostoma polylepis willkommii, in a first-order river in southern Spain. Folia Zoologica, 46: 123-133.

ENCINA L. \& C. GRANADO-LORENCIO. (1997d). Food habitat and food resource partitioning in three coexisting Barbus species. Folia Zoologica, 46 (4): 325-336.

ENCINA, L., A. RODRÍGUEZ-RUIZ, C. GRANADO-LORENCIO y C. ESCOT. 2001. Gestión y evaluación de embalses. Estudio de las poblaciones de peces. Universidad de Sevilla y COPT. Sevilla. 218 pp.

ENCINA, L. \& A. RODRÍGUEZ-RUIZ. 2002. Patterns of seasonal distribution of the fish assemblage in a reservoir of recent construction. Verh. Internat. Verein. Limnol., 28: 641-650.

ENCINA, L., A. RODRÍGUEZ-RUIZ \& C. GRANADO-LORENCIO. (2004). Trophic habits of the fish assemblage in new freshwater ecosystems: The Joaquin Costa reservoir. Folia Zoologica, 53(4): 437-449.

GARCÍA-NOVO, F. 1997. La conservación. ¿Será posible conservar nuestra fauna piscícola continental? En: Conservación, Recuperación y Gestión de la Ictiofauna Continental Ibérica. C. Granado-Lorencio (ed.).:7-28. Publicaciones de la Estación de Ecología Acuática. Sevilla.

GARCÍA-NOVO, F. 2000. Prólogo. En: Gestión y Evaluación de Embalses. Estudio de las Poblaciones de Peces. L. Encina, A. Rodríguez-Ruiz, C. Granado-Lorencio y C. Escot (eds.).: 13-22. Universidad de Sevilla. Sevilla.

GRANADO-LORENCIO, C. 1992. Fish species ecology in spanish freshwater ecosystems. Limnetica, 8: $255-261$.

GRANADO-LORENCIO, C. 1996. Ecología de Peces. Secretariado de Publicaciones de la Universidad de Sevilla. Sevilla. 353 pp. 
GRANADO-LORENCIO, C. 2000. Ecología de Comunidades. El paradigma de los peces de agua dulce. Secretariado de Publicaciones de la Universidad de Sevilla. Sevilla. 282 pp.

GRANADO-LORENCIO, C., L. ENCINA, C. ESCOT, E. MELLADO Y A. RODRÍGUEZRUIZ. 1996. Una nueva metodología para la estima de las poblaciones de peces en embalses. Ingeniería Civil, 103: 35-46.

GRANADO-LORENCIO, C., L. ENCINA, A. RODRÍGUEZ-RUIZ, C. ESCOT, E. MELLADO, A. BASANTA, A. MARTÍN, A. DÍAZ, A. CÁRDENAS Y R. GONZÁLEZ. 1997. Nuevas técnicas de gestión y evaluación íctica aplicables a ríos y embalses para el control de las poblaciones de peces y su utilización como indicadores de la calidad ambiental. Monografías del Centro de las Nuevas Tecnologías del Agua, 1-18.

GRANADO-LORENCIO, C., L. ENCINA, C. ESCOT, E. MELLADO \& A. RODRÍGUEZRUIZ. 1998. Estudio ictiológico en el embalse de Joaquín Costa (Río Ésera, Huesca). Limnetica, 14: $35-45$

GRANADO-LORENCIO, C., A. RODRÍGUEZRUIZ, L. ENCINA, C. ESCOT, E. MELLADO Y J. PRENDA. 2000. Ecología del Alto Guadalete. Bases para su conservación. Junta de Andalucía. Sevilla. 98 pp.

HILBORN, R. \& D. LUDWIG. 1993. The limits of applied ecological research. Ecological Applications, 3: 550-552.

HOFER, R. 1991. Digestion. In: Cyprinid fishes. Systematics, biology and exploitation. I. J. Winfield \& J. S. Madison (eds.).: 413-425. Chapman \& Hall. Londres.

HUTCHINSON, G. E. 1981. El teatro ecológico y el drama evolutivo. Ed. Blume. Barcelona. $151 \mathrm{pp}$.

LOBÓN-CERVIÁ, J. 2001. Entre ríos y peces, 20 años de intensa investigación. En: Atlas y Libro Rojo de los Peces Continentales de España I. Doadrio (ed.).: 36-39. CSIC y Ministerio de Medio Ambiente. Madrid.

MAGALHAES, M. F. 1992. Feeding of an iberian stream cyprinid assemblage: seasonality of resource use in a highly variable environment. Oecologia, 96: 253-260.

MARGALEF, R. 1982. Ecología. Omega. Barcelona. $951 \mathrm{pp}$.

PIANKA, E. R. 1982. Ecología evolutiva. Omega. Barcelona. 365 pp.

POPPER, K. R. 1992. Conocimiento objetivo. Tecnos. Madrid. 342 pp.

RINCÓN, P. A., J. C. VELASCO, N. GONZÁLEZSÁNCHEZ Y C. POLLO. 1990. Fish assemblahes in small streams in western Spain: the influence of an introduced predator. Arch. Hydrobiol. 118 (1): 81-91.

RODRÍGUEZ-RUIZ, A. 1992. Relación entre la comunidad íctica y la estructura del hábitat en un río de régimen mediterráneo. Tesis Doctoral. Universidad de Sevilla. Sevilla. 399 pp.

RODRÍGUEZ-RUIZ, A. \& C. GRANADO-LORENCIO. 1992. Spawning period and migration of three species of cyprinids in a stream with mediterranean regimen (SW Spain). J. Fish. Biol., 41: 545-556.

RODRÍGUEZ-RUIZ, A., L. ENCINA. Y C. GRANADO-LORENCIO. 1998. Estrategias de vida de las especies ícticas en un río fluctuante en el sur de España: una visión holística. Boletín de la Sociedad de Biología de Concepción, 69: 175-189.

RODRÍGUEZ-RUIZ, A., L. ENCINA \& C. GRANADO-LORENCIO. 2002. Changes in the Iberian nase, Chondrostoma willkommii, population in the Guadalete River (Spain) following impoundment. In: Conservation of freshwater fishes: options for the future. M. J. Collares-Pereira, I. G. Cowx \& M. M. Coelho (eds.).: 283-290. Blackwell. Londres.

VARGAS, M. 1993. Interacción entre Aphanius iberus y Gambusia holbrooki en el Delta del Ebro: sus ciclos biológicos y ecología tróficas. Tesis Doctoral. Universidad de Barcelona. Barcelona. $173 \mathrm{pp}$

VELA DE PABLOS, I. 2003. Migración reproductiva de la ictiofauna del tramo alto del Río Guadalete (Parque Natural de Grazalema). Tesis de Licenciatura. Universidad de Sevilla. Sevilla. $126 \mathrm{pp}$. 


\title{
Biochemical fingerprints in zooplankton
}

\author{
Cástor Guisande \\ Edificio de Ciencias, Universidad de Vigo, Campus Lagoas-Marcosende, 36200 Vigo, SPAIN. \\ e-mail: castor@uvigo.es
}

\begin{abstract}
SUMMARY
The use of the role of the species in the habitat (the niche), rather than systematics, for studying the factors that determine which and how many species live in a specific habitat (community assembly), is an approach that has been limited by obvious difficulties in the characterization of the niche. This study shows that is possible to use biochemical fingerprints as indicators of both "requirement niche" and "impact niche" in zooplankton species. Protein content is a good indicator of the nutritive state of the animals and, also, it is a good tool for elucidating food-competitive capacities among species. Reproductive success is positively related with the organic content of the egg (the sum of proteins, carbohydrates, and lipids). Finally, the amino acid composition of the species is a good indicator of the trophic niche and the adaptations of the species to abiotic factors.
\end{abstract}

Key words: Proteins, carbohydrates, lipids, amino acids, zooplankton, copepods, cladocerans, rotifers, niche, community assembly.

\section{RESUMEN}

La utilización del papel de las especies en el hábitat (el nicho), en lugar de la sistemática, para estudiar los factores que determinan cuantas y cuales especies viven en un hábitat (ensamblaje de la comunidad), se ha visto limitado por dificultades obvias a la hora de caracterizar el nicho. Este estudio muestra que es posible usar huellas bioquímicas como indicadores del "nicho de requisitos" y el "nicho de impacto" en especies del zooplancton. El contenido en proteinas es un buen indicador del estado nutritivo de los animales y también es una herramienta útil para dilucidar entre las capacidades competitivas de las especies por el alimento. El éxito reproductivo está relacionado positivamente con el contenido orgánico del huevo (la suma de proteinas, carbohidratos y lípidos). Finalmente, la composición de aminoácidos de las especies es un buen indicador del nicho trófico y de las adaptaciones de las especies a los factores abióticos.

Palabras clave: proteínas, carbohidratos, lípidos, aminoácidos, zooplancton, copépodos, cladóceros, rotiferos, nicho, ensamblaje de comunidades.

\section{INTRODUCTION}

One of the main aims of Ecology is to determine the processes that determine which and how many species live in a specific habitat (community assembly). The identification of the main factors structuring the assemblage of the zooplankton communities usually relies on studies based on the co-occurrence (or lack of it) of species, and changes in the abundance of the species according to changes in the abiotic factors.

A different approach for studying community assembly is to compare the niches of the species. For instance, if the main factor structuring a community were a depletable factor in the environ- ment, hence potentially limiting, then the coexistence of the species would be the result of a reduced overlap in resource use and, therefore, the niche of the species would be different. Cooccurring species would have a similar niche, if the assemblage of the community were mainly governed by environmental factors that limit populations (e.g., temperature, salinity, etc).

The ecological approach based on niche comparison has been limited by obvious difficulties in the characterization of the niche of the species. A correct description of the niche requires characterising the two distinct niche components (Leibold, 1995): 1) the requirement niche, describing the response of the species to the 
environment and, 2) the impact niche, describing the effect of the species on the habitat.

In this review I show that it is possible to describe both the requirement niche and the impact niche of zooplankton species, by using some biochemical fingerprints. These fingerprints are indicators of the optimal growth and reproduction of zooplankton species for the different ecological factors. Therefore, they are indicators of the adaptations of the species to the abiotic factors (requirement niche), and also of the differential use of the niche (impact niche).

\section{NUTRITIONAL CONDITION}

Food availability is one of the most important factors affecting the population dynamics of zooplankton species (Threlkeld, 1976; Tessier \& Goulden, 1982; Gliwicz 1985; Guisande \& Toja, 1988; Duncan, 1989; Müller-Navarra \& Lampert 1996). The amount of food affects intraspecific variations in population abundance because it controls the reproductive output, but it may also play a significant role in determining the cooccurrence of zooplankton species, because of the exclusion of those with lower competitive abilities or the co-existence of others as a result of a reduced overlap in food resource use.

Field studies have shown that there is a log positive relationship between protein content of the individuals and food abundance (Serrano \& Guisande, 1989; Guisande et al., 1991b). Therefore, protein content of the animals is a good indicator of the nutritive state in zooplankton, i.e., if the species is food limited or is at the optimum nutritive state in the habitat.

Moreover, the protein content-length regressions allow for determining which species are favoured when food concentration is low (Guisande et al., 1991b) and hence, it is a good tool for elucidating food competitive abilities among species. Figure 1 is an example that protein content may be a good tool for comparing competitive abilities among zooplankton species. The protein content was higher in the benthic than in the planktonic species collected from Pyrenean lakes (Fig. 1). Therefore, in

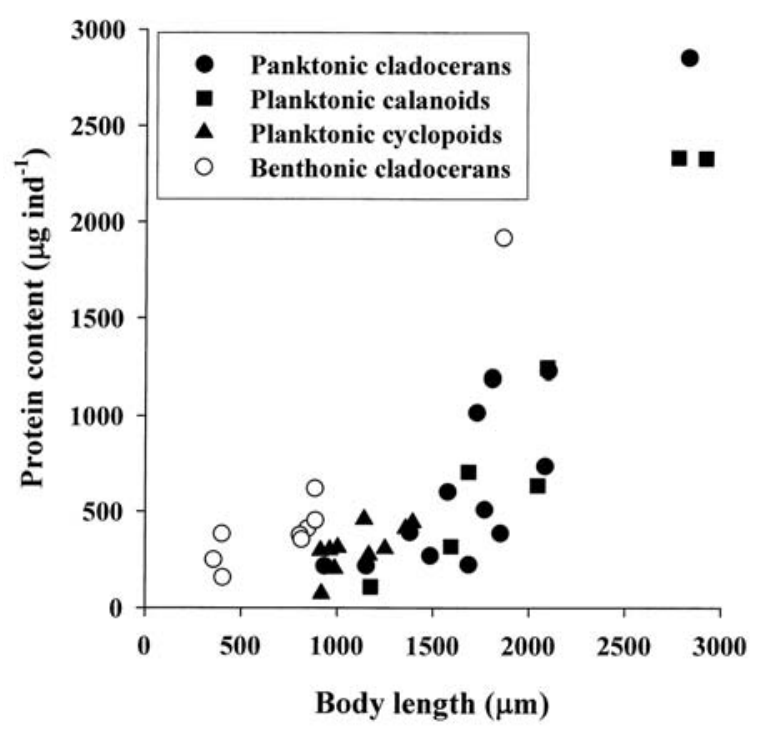

Figure 1. Relationship between body length and protein content, considering only 15 amino acids (see Guisande et al., 2003), of different species of cladocerans, diaptomids and cyclopoids collected from Pyrenean mountain lakes. Relación entre la longitud del cuerpo y el contenido en proteínas, considerando sólo 15 amino ácidos (ver Guisande et al., 2003), de diferentes especies de cladóceros, diaptómidos y ciclópidos recolectados en lagos de montaña del Pirineo.

these oligotrophic lakes, it seems that those species that can feed on periphyton or detritus, which are mainly found on the water body bottom, may have a competitive advantage in comparison with planktonic species.

Protein content also allows for the discrimination between the behaviour of individuals or subpopulations (Guisande et al., 1991a). Zooplankton species perform diel vertical migrations as a trade-off between reduced mortality and reduced output due to lower food availability in their refuge. Length-body protein regression in cladocerans, as a measure of nutritional state, allowed for the discrimination between migrating and nonmigrating individuals of Daphnia hyalina-galeata (Guisande et al., 1991a). The daphnids that remain in the surface and, hence, do not migrate, have a higher protein content than those animals that do migrate. Therefore, in addition to discriminate between migrating and non-migrating animals, the protein content, as an indicator of nutritional condition, also allowed for the demonstration that migrating animals gain no metabolic advantage over non-migrating ones. 


\section{REPRODUCTIVE SUCCESS}

In addition to changes in breeding intensity, much of the seasonal change in population densities of zooplankton species can also be ascribed to variability in reproductive success.

Zooplankton species are able to modify their reproductive strategy according to changes in temperature, food level, intra-specific competition and/or risk of predation, in order to maximize offspring fitness (see for review Guisande \& Gliwicz, 1992; Guisande 1993). The change in reproductive strategy is usually associated to a trade-off between offspring size and number (see Guisande \& Mazuelos, 1991; Guisande et al., 1996), which represents a compromise between neonate fitness and maximum possible clutch size (Tessier \& Consolatti, 1989). Since egg size varies directly with protein, carbohydrate, and lipid content of the eggs (Guisande \& Gliwicz, 1992; Guisande, 1993; Galindo et al, 1993; Guisande \& Harris, 1995), and offspring survival depends on the biochemical composition of the egg (Guisande \& Gliwicz, 1992; Guisande et al., 1993; Guisande \& Harris, 1995; Guisande et al., 1996; Guisande et al., 1998; Riveiro et al., 2000; 2004), the organic content of the egg is a good indicator of reproductive success in zooplankton species.

Reproductive success also depends on food quality. A diet that is optimally balanced is an important factor affecting zooplankton reproductive success (see for review Guisande et al, 1999). If the biochemical composition of the food is too different from the biochemical composition of the zooplankton species, the lag time between food ingested and it being converted into the production of eggs is probably too short to produce eggs with an optimal proportion of biomolecules (amino acids, fatty acids, etc.) and elements (N, P, etc). Therefore, food quality may be an important factor affecting the population dynamics of zooplankton species, but the problem is the difficulty of quantifying food quality. A higher reproductive success is observed as the amino acid composition of copepod species becomes closer to the amino acid composition of food (Guisande et al, 1999). Therefore, the comparison between the amino acid composition of zooplankton species and their food is a good indicator of food quality.

\section{AMINO ACID COMPOSITION AS AN INDICATOR OF DIFFERENTIAL USE OF NICHE AND THE ADAPTATION TO THE ABIOTIC ENVIRONMENT}

Amino acid composition is species-specific. A biochemical fingerprint, which informs about the differential use of the niche of the species and the adaptation to the environment, must be speciesspecific. This has been demonstrated in zooplankton species (Guisande et al., 2002; 2003; Riveiro et al., 2003; Boëchat \& Adrian, 2005).

A discriminant analysis performed on the amino acid composition of cladocerans, cyclopoids and calanoids from Pyrinean lakes with altitudes ranging between 1,875 and $2,990 \mathrm{~m}$ (Guisande et al., 2003), and rotifers from peridunar ponds of Doñana National Park revealed that the percentage of species correctly classified was $86.3 \%, 94.1 \%, 100 \%$ and $94.2 \%$ respectively (Fig. 2). Therefore, despite the intraspecific variation, it is possible to identify each species according to its amino acid composition.

\section{Trophic niche}

Food resource partitioning may play a significant role in determining the co-occurrence of zooplankton species. However, evidence of exploitative competition usually relies on the co-existance (or lack of it) of species assigned to functional groups or guilds based solely on systematics. Few studies have directly examined the types of food consumed by zooplankton or the way in which food is gathered, because there are obvious difficulties in performing field observations of food use.

The amino acid composition of zooplankton species can be used to study food resource partitioning in zooplankton communities because it is a good indicator of both the "requirement niche" and the "impact niche" (Leibold, 1995). 

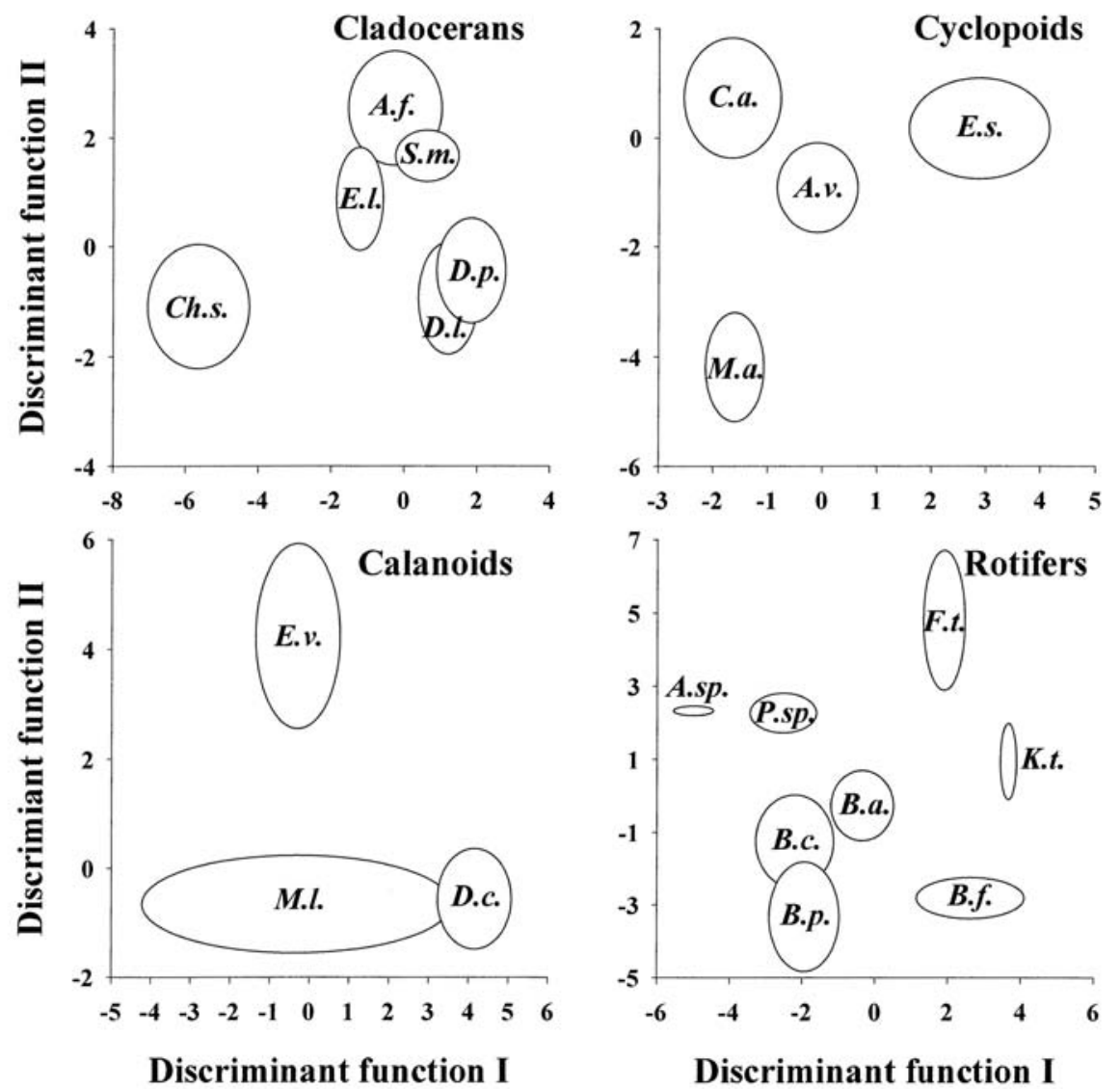

Figure 2. Plots of the mean $\pm \mathrm{SD}$ of first two discriminant function scores for the amino acids of the species. Species abbreviation: Daphnia longispina (D.l.), Daphnia pulicaria (D.p.), Alona affinis (A.f.), Chydorus sphaericus (Ch.s.), Scapholeberis mucronata (S.m.), Eurycercus lamellatus (E.l.), Cyclops abyssorum (C.a.), Macrocyclops albidus (M.a.), Acanthocyclops vernalis (A.v.), Eucyclops serrulatus (E.s.), Eudiaptomus vulgaris (E.v.), Diaptomus cyaneus (D.c.), Mixodiaptomus laciniatus (M.l.), Poyarthra sp. (P.sp.), K. tropica (K.t.), Filinia terminalis (F.t.), B. plicatilis (B.p.), B. falcatus (B.f.), B. calyciflorus (B.c.), B. angularis (B.a) and Asplanchna sp. (A.sp.). Representación de la media $\pm D E$ de las dos primeras funciones discriminantes de los amino ácidos de las especies. Abreviación de las especies: Daphnia longispina (D.1.), Daphnia pulicaria (D.p.), Alona affinis ( A.f.), Chydorus sphaericus (Ch.s.), Scapholeberis mucronata (S.m.), Eurycercus lamellatus (E.1.), Cyclops abyssorum (C.a.), Macrocyclops albidus (M.a.), Acanthocyclops vernalis (A.v.), Eucyclops serrulatus (E.s.), Eudiaptomus vulgaris (E.v.), Diaptomus cyaneus (D.c.), Mixodiaptomus laciniatus (M.1.), Poyarthra sp. (P.sp.), K. tropica (K.t.), Filinia terminalis (F.t.), B. plicatilis (B.p.), B. falcatus (B.f.), B. calyciflorus (B.c.), B. angularis (B.a) y Asplanchna sp. (A.sp.).

Guisande et al., (1999; 2000; 2002) showed that the amino acid composition of some marine copepods is species-specific and remains relatively constant despite distinct nutritional supplies, and there are important differences in the amino acid composition among zooplankton and phytoplankton species (Guisande et al., 1999). Moreover, the more similar the amino acid composition of the food to the amino acid composition of the species, the greater the reproductive success (Guisande et al., 1999).
Therefore, amino acid composition is a good indicator of the "requirement niche" for optimal growth and reproduction. On the other hand, although it has been shown that copepods can assimilate some amino acids selectively (Cowie \& Hedges, 1996), the main differences in amino acid composition among zooplankton species are mainly due to differences in diet (Guisande et al., 2002). Therefore, zooplankton amino acid composition is also a good indicator of the "impact niche" of each species. 
Mountain lakes are an appropriate setting in which to study the role of food resource partitioning in zooplankton, mainly because these lakes are oligotrophic to ultra-oligotrophic, thus food limitation may have played a significant role in evolutionary history. Guisande et al., (2003) analysed the amino acid composition of 6 cladocera and 7 copepod species from 29 Pyrenean mountain lakes. A discriminant analysis showed that each species could be distinguished according to its amino acid composition. A negative relationship between amino acid differentiation and co-occurrence among the cladocera and cyclopoid copepod was observed. As the differences in the amino acid composition among zooplankton species indicate distinct food sources (Guisande et al., 2002; McClelland \& Montoya, 2002), the relationship found indicates that trophic-niche differentiation plays a key role in determining the assemblage of these zooplankton communities. Therefore, by driving co-evolutionary histories either at present or in the past, exploitative competition played a significant factor in structuring the cladocera and cyclopoid communities in these oligotrophic lakes.

\section{Abiotic niche}

In the previous section it was shown that amino acid composition of zooplankton species is a good indicator of the trophic niche of the species. Protein expression can also be directly related to stress in that proteins are used by zooplankton species to adapt to changing habitat conditions (Kimmel \& Bradley, 2001). Therefore, amino acid composition may also provide a natural tag for the adaptation of each species to its habitat, in other words, information about the abiotic niche of the species. The identification of common adaptations of co-occurring species may allow identifying the main abiotic factors in structuring community assemblages.

In a study in ponds of Doñana National Park (SW, Spain), a negative relationship between amino acid separation and spatial overlap among rotifer species was observed, indicating that those species with a similar amino acid composition have a higher spatial overlap.

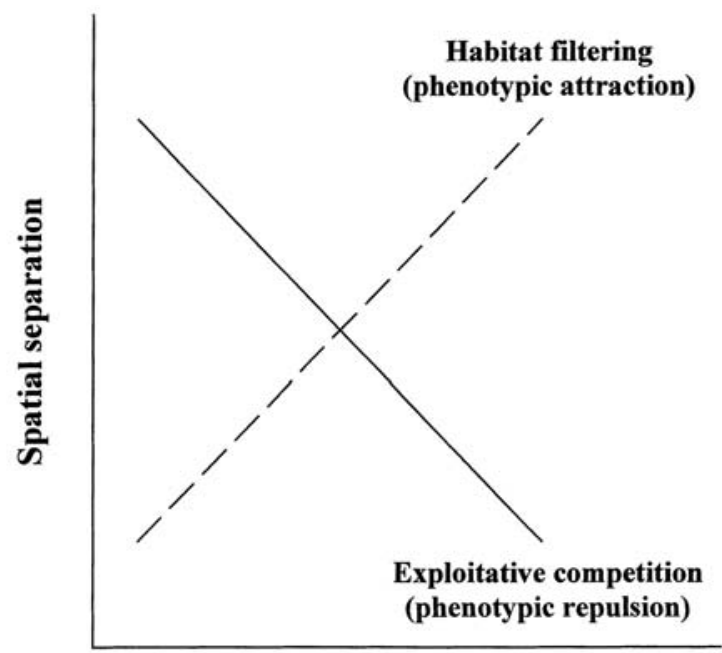

Amino acid separation

Figure 3. Theoretical relationship between amino acid composition separation and spatial overlap among species under a situation of phenotypic repulsion (solid line) and phenotypic attraction (dashed line). Relación teórica entre la separación de la composición de amino ácidos y el solapamiento espacial entre especies bajo una situación de repulsión fenotípica (linea continua) y atracción fenotípica (línea discontinua).

Therefore, there is an opposite pattern in the rotifer community of the ponds in contrast to the one observed in cladocera and copepods of Pyrenean lakes (Guisande et al., 2003). Those species with a similar amino acid composition and hence, with a similar trophic niche, spatially co-occur, indicating that trophic-niche differentiation was not the main factor in structuring rotifer assemblages in the ponds.

The high similarity in the amino acid composition among co-occurring species could be interpreted as evidence for a predominant role in habitat filtering, indicating the relevant role of abiotic factors on the assemblages of the rotifer community in the ponds. The positive relationship between amino acid separation and species separation according to their weighted mean for the concentration of silicates indicates that salinity was the main abiotic factor in structuring the assembly of rotifer communities in the ponds.

Therefore, amino acid composition of zooplankton species, in addition to being speciesspecific and a good indicator of the trophic niche of the species (Guisande et al., 2002; 2003; McClelland \& Montoya, 2002; Boëchat 
\& Adrian, 2005), is also a good indicator of the adaptation of the species to the abiotic conditions of the habitat. Therefore, amino acid composition is a good indicator of the ecological niche of zooplankton species and therefore, a good tool to elucidate the way zooplankton communities assemble from a regional pool of species. The relationship between amino acid separation and spatial separation among zooplankton species will be negative when exploitative competition (phenotypic repulsion), either at present or in the past by driving coevolutionary histories, is the most significant factor in structuring the zooplankton community (Fig. 3). The relationship will be positive when there is a predominant role for habitat filtering (phenotypic attraction).

\section{ACKNOWLEDGMENTS}

Many thanks to all the people who collaborated with me during these years. The research along all these years was supported by several projects: CICYT MAR95-1791, CICYT MAR96-1822, CICYT MAR99-0328-C03-01, PGIDT00PXI30107, CE EVK3-2001-00050, PGIDIT02PXIC30105PM, CICYT REN200204205-C04-01, PGIDIT03PXIC30106PN and PGIDT04PXIC31001PM.

\section{BIBLIOGRAPHY}

BOËCHAT, I. G. \& R. ADRIAN. 2005. Biochemical composition of algivorous freshwater ciliates: You are not what you eat. FEMS Microl. Ecol., 53: 393-400.

COWIE G. L. \& J. I. HEDGES. 1996. Digestion and alteration of the biochemical constituents of a diatom (Thalassiosira weissflogii), ingested by an herbivorous zooplankton (Calanus pacificus). Limnol. Oceanogr., 41: 581-594.

DUNCAN A. 1989. Food limitation and body size in the life cycles of planktonic rotifers and cladocerans. Hydrobiologia, 186/187: 11-28.

GALINDO, M. D., C. GUISANDE \& J. TOJA. 1993. Reproductive investment of several rotifer species. Hydrobiologia, 255/256: 317-324.
GLIWICZ, Z. M. \& C. GUISANDE. 1992. Family planning in Daphnia: resistance to starvation in offspring born to mothers grown at different food levels. Oecologia, 91: 463-467.

GLIWICZ, Z. M. 1985. Predation or food limitation: an ultimate reason for extinction of planktonic cladocera species. Arch. Hydrobiol. Beih. Ergebn. Limnol., 39: 419-430.

GUISANDE, C. \& J. TOJA. 1988. The dynamics of various species of the genus Brachionus (ROTATORIA) in the Guadalquivir river. Archiv. Hydrobiol., 112: 579-595.

GUISANDE, C. \& L. SERRANO. 1989. Analysis of protein, carbohydrate and lipid in rotifers. Hydrobiologia, 186/187: 339-346.

GUISANDE, C. \& N. MAZUELOS. 1991. Reproductive pattern of Brachionus calyciflorus Pallas at different food concentrations. J. Plankton Res., 13: 279-286.

GUISANDE, C., A.DUNCAN. \& W. LAMPERT. 1991a. Trade-offs in Daphnia vertical migration strategies. Oecologia, 87: 357-359.

GUISANDE, C., J. TOJA \& N. MAZUELOS. $1991 b$. The effect of food on protein content in rotifer and cladoceran species: a field correlational study. Freshwat. Biol., 26: 433-438.

GUISANDE, C. \& Z. M. GLIWICZ. 1992. Egg size and clutch size in two Daphnia species grown at different food levels. J. Plankton Res., 14: 997-1007.

GUISANDE, C. 1993. Reproductive strategy as population density varies in Daphnia magna (CLADOCERA). Freshwat. Biol., 29: 463-467.

GUISANDE, C., M. D. GALINDO, F. M. GALAN \& F. OLIVEROS. 1993. The cost of reproduction in the rotifer Brachionus calyciflorus. Int. Revue ges. Hydrobiol., 78: 493-499.

GUISANDE, C. \& R. HARRIS. 1995. Effect of total organic content of eggs on hatching success and naupliar survival in the copepod Calanus helgolandicus. Limnol. Oceanogr., 40: 476-482.

GUISANDE, C., J. SÁNCHEZ, I. MANEIRO \& A. MIRANDA. 1996. Trade-off between offspring number and offspring size in the marine copepod Euterpina acutifrons DANA at different food concentrations. Mar. Ecol. Progr. Ser., 143: 37-44.

GUISANDE, C., I. RIVEIRO, A. SOLÁ \& L. VALDÉS. 1998. Effect of biotic and abiotic factors on the biochemical composition of wild eggs and larvae of several fish species. Mar. Ecol. Prog. Ser., 163: 53-61.

GUISANDE, C., I. MANEIRO \& I. RIVEIRO. 1999. Homeostasis in the essential amino acid composi- 
tion of the marine copepod Euterpina acutifrons. Limnol. Oceanogr., 44: 691-696.

GUISANDE, C., I. RIVEIRO \& I. MANEIRO. 2000. Comparison between the amino acid composition of females, eggs and food to determine the relative importance of food quantity and food quality on copepod reproduction. Mar. Ecol. Progr. Ser., 202: 135-142.

GUISANDE, C., I. MANEIRO, I. RIVEIRO, A. BARREIRO \& Y. PAZOS. 2002. Estimation of copepod trophic-niche in the field using amino acids and marker pigments. Mar. Ecol. Progr. Ser., 239: 147-156.

GUISANDE, C., F. BARTUMEUS, M. VENTURA \& J. CATALAN. 2003. Role of food partitioning in structuring the zooplankton community in mountain lakes. Oecologia, 136: 627-634.

KIMMEL, D. G. \& B. P. BRADLEY. 2001. Specific protein responses in the calanoid copepod Eurytemora affinis (Poppe, 1880) to salinity and temperature variation. J. Exp. Mar. Biol. Ecol., 266: 135-149.

LEIBOLD, M. A. 1995. The niche concept revisited: Mechanistic models and community context. Ecology, 76: 1371-1382.

MCCLELLAND, J. W. \& J. P. MONTOYA. 2002. Trophic relationships and the nitrogen isotopic composition of amino acids in plankton. Ecology,
83: 2173-2180.

MÜLLER-NAVARRA D. \& W. LAMPERT. 1996. Seasonal patterns of food limitation in Daphnia galeata: separating food quantity and food quality effects. J. Plankton Res., 18: 1137-1157.

RIVEIRO, I., C. GUISANDE, M. LLOVES, I. MANEIRO \& J. M. CABANAS. 2000. Importance of parental effect on larval survival in Sardina pilchardus. Mar. Ecol. Prog. Ser., 205: 249-258.

RIVEIRO I, C. GUISANDE, C. FRANCO, A. LAGO DE LANZÓS, I. MANEIRO I \& A. R. VERGARA. 2003. Egg and larval amino acid composition as indicators of niche resource partitioning in pelagic fish species. Mar. Ecol. Progr. Ser., 260: 255-262.

RIVEIRO, I., C. GUISANDE, I. MANEIRO \& A. R. VERGARA. 2004. Parental effects in the European sardine (Sardine pilchardus). Mar. Ecol. Progr. Ser., 274: 225-234.

THRELKELD S. T. 1976. Starvation and the size structure of zooplankton communities. Freshwat. Biol., 6: 489-496.

TESSIER, A. J. \& N. L. CONSOLATTI, 1989. Variation in offspring size in Daphnia and consequences for individual fitness. Oikos, 56: 269-276.

TESSIER, A. J. \& C. E. GOULDEN. 1982. Estimating food limitation in cladocera populations. Limnol. Oceanogr., 27: 707-717. 